\title{
Systematic Literature Review: Integration of Additive Manufacturing and Industry 4.0
}

\author{
Mario Enrique Hernandez Korner ${ }^{1,2}, *\left(\mathbb{0}\right.$, María Pilar Lambán ${ }^{2}{ }^{(0}$, José Antonio Albajez ${ }^{2}(\mathbb{D}$, \\ Jorge Santolaria $^{2}$, Lisbeth del Carmen $\mathrm{Ng}$ Corrales ${ }^{1,2} \oplus$ and Jesús Royo ${ }^{2}$ \\ 1 Department of Industrial Engineering, Universidad Tecnológica de Panamá, Ciudad de Panama 0819-07289, \\ Panama; lisbeth.ng@utp.ac.pa \\ 2 Design and Manufacturing Engineering Department, Universidad de Zaragoza, 50018 Zaragoza, Spain; \\ plamban@unizar.es (M.P.L.); jalbajez@unizar.es (J.A.A.); jsmazo@unizar.es (J.S.); jaroyo@unizar.es (J.R.) \\ * Correspondence: mario.hernandez2@utp.ac.pa; Tel.: +34-633-139-638
}

Received: 1 July 2020; Accepted: 2 August 2020; Published: 6 August 2020

\begin{abstract}
The research trend in additive manufacturing (AM) has evolved over the past 30 years, from patents, advances in the design, and layer-by-layer materials, to technologies. However, this evolution is faced with some barriers, such as the implementation of additive manufacturing (AM) in operations, its productivity limitations, and economic and social sustainability. These barriers need to be overcome in order to realize the full potential of AM. The objective of this study is to analyze the bibliometric data on these barriers through a systematic review in two study areas: business model innovation and sustainability in AM from Industry 4.0 perspective. Using the most common keywords in these two study areas, we performed a search on the Web of Science (WoS) and Scopus databases and filtered the results using some inclusion and exclusion criteria. A bibliometric analysis was performed for authorship productivity, journals, the most common keywords, and the identified research clusters in the study areas. For the bibliometric analysis, the BIBEXCEL software was used to extract the relevant information, and Bibliometrix was used to determine the research trend over the past few years. Finally, a literature review was performed to identify future trends in the study areas. The analysis showed evidence of the relationship between the study areas from a bibliometric perspective and areas related to AM as an enabler for Industry 4.0.
\end{abstract}

Keywords: literature review; bibliometric analysis; Industry 4.0; additive manufacturing; business model; sustainability

\section{Introduction}

The research trend in additive manufacturing (AM)/3D printing/rapid prototyping has evolved over the past 30 years from a rapid prototyping technology to advanced manufacturing. According to Mohsen [1], the third industrial revolution started in 1987 with the commercialization of the first stereolithography (SLA) machine, named SLA-1, developed by 3D Systems. After several commercialized versions of SLA machines in 1991, three new AM-based technologies were commercialized: fused deposition modeling (FDM), solid ground curing, and laminated object manufacturing (LOM). This was followed by several years of sustained development in the AM technology from using resin to metal powder and from non-functional molding applications to fabricating medical implants [2]. At present, the focus is on the implementation of this technology in the manufacturing environment [3], considering business/operations cost implications [1,4-7], design for manufacturing or design optimization [8], and the sustainable development of this technology considering environmental implications such as the product life cycle, circular economy (CE), and use of recycled materials [9-11]. Few studies have reviewed the business innovation (BI) and sustainable 
development of the AM technology separately [12-16]. Industry 4.0 technologies facilitate decision making using real-time data $[17,18]$, but others give more importance to how effective Industry 4.0 data are for environmentally sustainable implications $[19,20]$. Therefore, a systematic literature review and a bibliometric analysis of the AM business model and sustainability areas are needed to consider the integration of these developments into Industry 4.0. The objective of this review is to analyze the bibliometric data based on these two key aspects in the AM field and theirs integration into Industry 4.0 as an enabler of it and to provide a foundation on which future research may be built.

The remainder of this review is organized as follows. The backgrounds of additive manufacturing and Industry 4.0 are discussed in Section 2. The guidelines for the review and the methodology adopted for article selection are discussed in Section 3. The results of the bibliometric and literature review are analyzed in Section 4.

\section{Background}

\subsection{Additive Manufacturing}

As defined by the American Society for Testing and Materials (ASTM) and the ISO/TC 261 Committee for Standardization in Additive Manufacturing, additive manufacturing is a collection of technologies able to join materials to make objects from 3D model data, usually layer upon layer, as opposed to the subtractive manufacturing methodologies [21].

In the existing literature, AM processes have been classified by various parameters: materials used, direct or indirect process technology, and the state of the raw material used (which is one of the most commonly used basis) (See Figure 1).

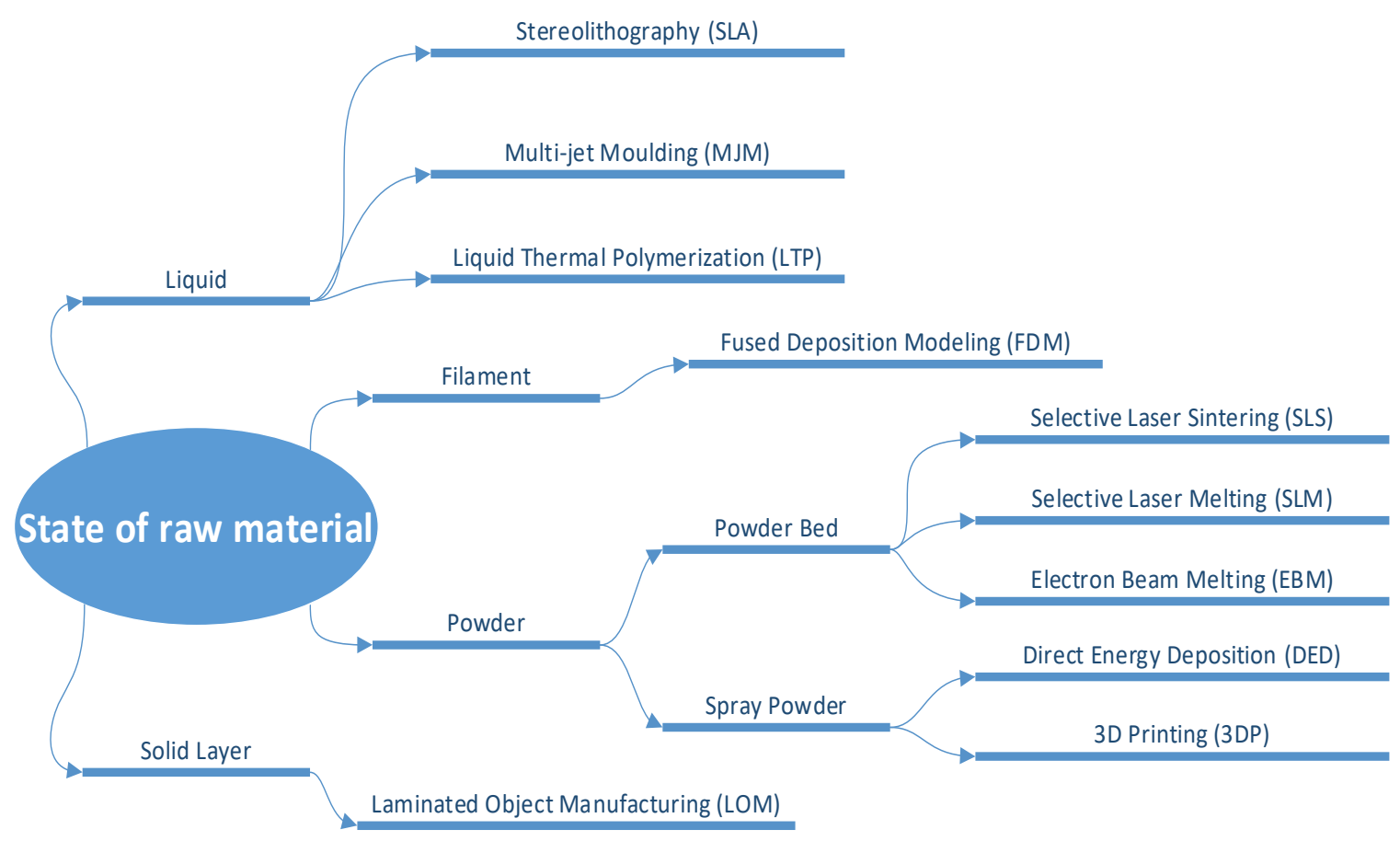

Figure 1. Types of additive manufacturing processes based on state of raw materials.

Past research indicated significant advances in the AM technology in terms of its applications [22-26], economic impact [3,27-29], use of raw materials [30-32], and design [33-35]. To the best of our knowledge, the filament and powder are the most frequently used raw materials for cost characterization, business model proposals, and sustainability processes. Furthermore, the filament and powder are the most common AM technologies implemented for Industry 4.0 integration [36,37], and which are compared with traditional manufacturing methods [6,38-40]. 


\subsection{Industry 4.0}

In recent years, Industry 4.0 has seen significant advances in production processes, data management, cybersecurity, and competitiveness based on customization and client relationship (see Figure 2) [37,41-43]. Industry 4.0, well known as the fourth industrial revolution, was born in Germany as Industrie 4.0 in 2011 as a proposal to develop the German economy [44,45].

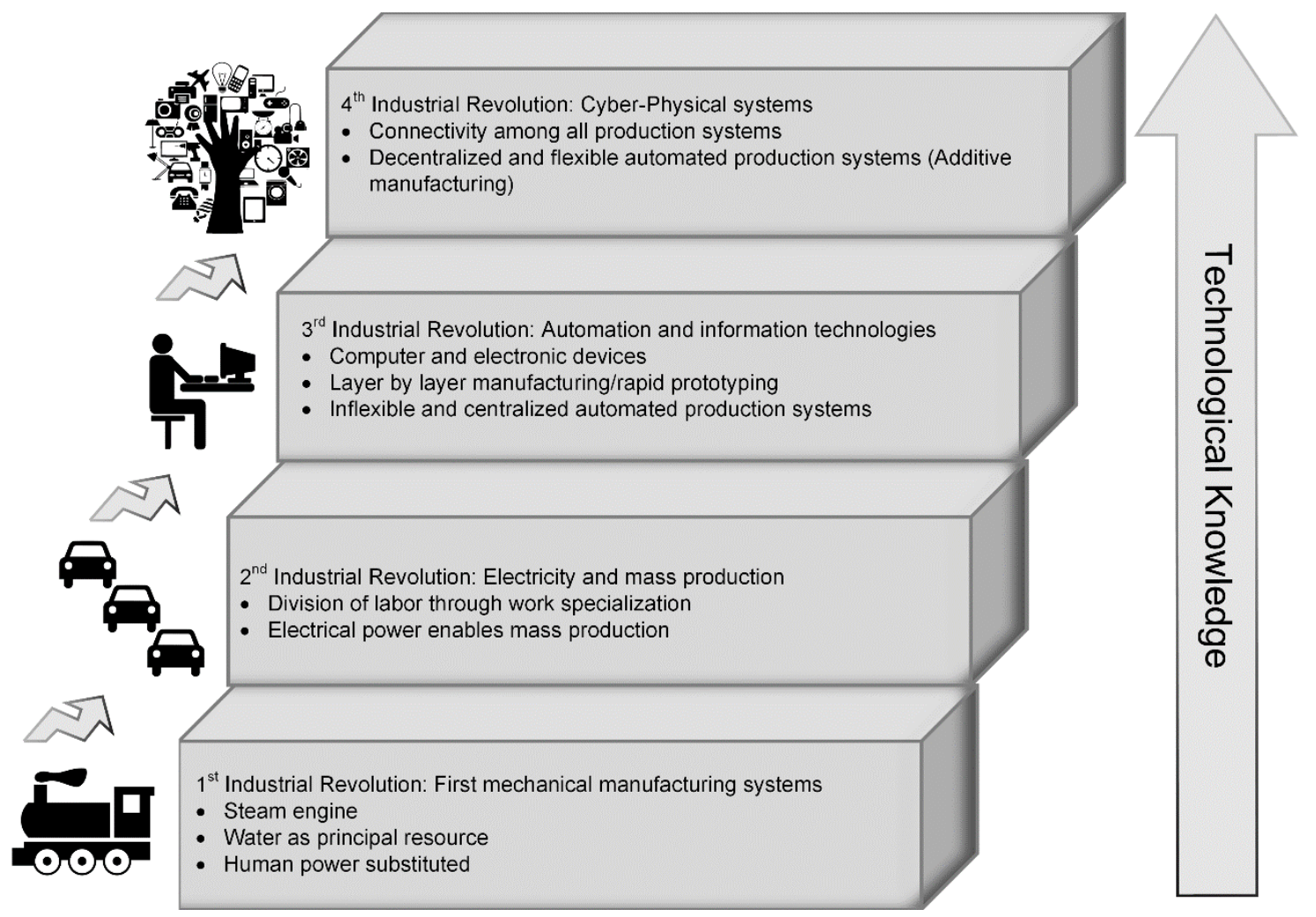

Figure 2. Industrial revolutions (adapted from $[46,47])$.

Industry 4.0 is characterized by interactions and communication among industrial equipment and cyber-physical systems for managing operations in real time [48] for decision-making, Internet of Things, artificial intelligence, robotics, cybersecurity, and 3D printing [49] (see Figure 3). By means of Industry 4.0, companies can use autonomous fabrication systems, make decentralized decisions, and facilitate interconnectivity among employees, machines, orders, suppliers, and customers $[18,50]$. Technology based on Industry 4.0 enables organizations to create products that meet customers' needs, and facilitates production parameter control such as energy consumption, material flow, and real-time monitoring [18].

Recent research established Industry 4.0 as an enabler of recent trends related to CE [36,42,51-53], innovation in businesses concerning manufacturing [43,54], new business models [55,56], and supply chain and cost model configuration [57].

The pursuit of increased competitiveness drives research in energy efficiency, resource redistribution, and smart equipment, which are key characteristics of Industry 4.0 [58]. The growth and proliferation of Industry 4.0 are related to the implementation of smart factories, smart products, cyber-physical systems, smart cities, and digital sustainability [45]. 


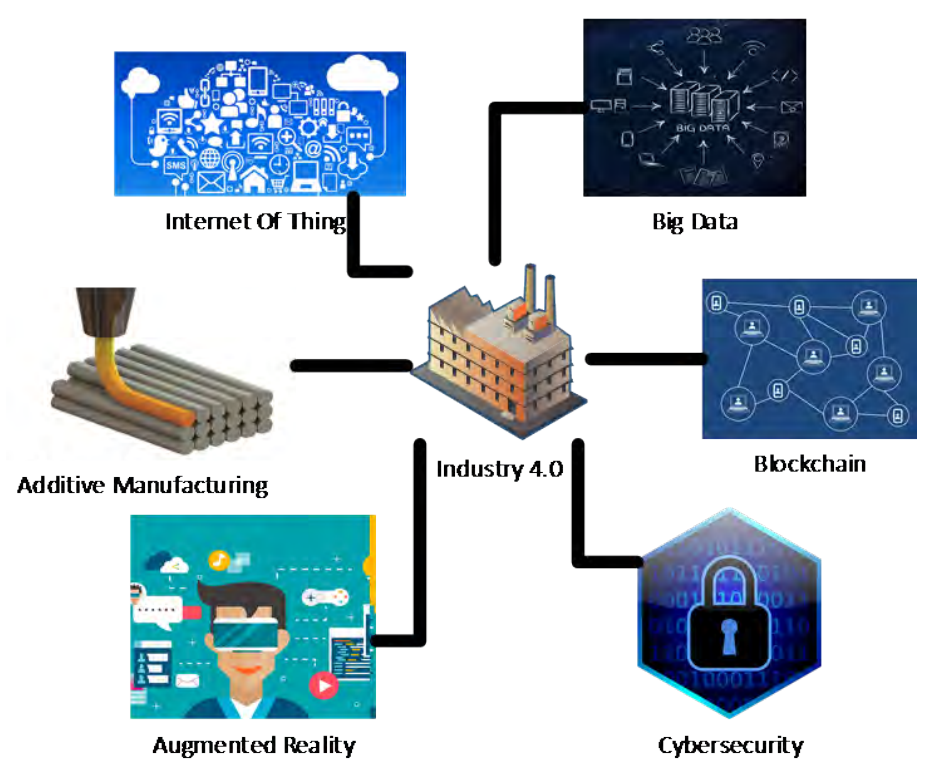

Figure 3. Industry 4.0 technological trends (adapted from [37]).

\section{Materials and Methods}

AM plays an important role in the six approaches presented in Figure 3 in the context of Industry 4.0 from the perspectives of sustainability and innovation in business. This systematic literature review and a bibliometric analysis considers the AM business model and sustainability in the context of its integration with Industry 4.0. The first objective of this review was to analyze the bibliometric data based on these two key aspects related to the AM topic and its integration with Industry 4.0 as an enabler of it. The second objective was to provide a foundation on which future research can be built. To this end, we established a research protocol to identify a set of specific publications from two scientific databases. Based on a systematic literature review, we summarized the existing information, determined a research protocol, and suggested areas for further study [59]. The objective of this methodology was to guide the review into three phases: planning, execution of the theoretical review, and reporting of results.

The first step in planning was the identification of the information sources. We selected the Web of Science (WoS) and Scopus databases: WoS has a wide coverage with citation and bibliographic data and Scopus is the largest database on the market for multidisciplinary scientific literature [60]. We identified the most common terminology associated with the two selected key aspects in AM, starting with the various terms for AM in the literature. For sustainability and business innovation, we searched for the most common terms associated with additive manufacturing. Next, we defined the following inclusion criteria to select articles for this review:

- I 1. Article type must be research paper, proceedings paper, or review

- I 2. Article must be in English

- I 3. Articles must be from 2018 Journal Citation Report

For the most common terms for AM, the search code used for both databases was ("additive manufactur *" OR "3D Print *" OR "rapid prototype *"), followed by the application of two different filters based on the objectives of this research. First was "sustainable development" OR "circular economy," which are frequently used terms for research associated with sustainable development in AM. The second was the "cost model" OR "cost characterization" OR "business model," which are terms associated with BI in AM. See Figure 4 for the exact codes used for searching the databases. Under certain assumptions, the classification of the two key aspects of this review can be construed as follows. The sustainability aspect of AM was divided into recycled raw materials, sustainable processes, and creation or implementation of sustainable technology for AM. Furthermore, the BI aspect 
of AM was divided into business model innovation, cost model characterization, AM operation cost, and supply-chain adaptation. These bibliographic data are useful for the bibliometric analysis using Bibexcel [61] and Bibliometrix R Studio package to visualize the relationship between the bibliographic data and trend [62]. Bibexcel is an open-source tool for various bibliometric analyses, and it can interface easily with other software such as Excel [61]. Bibliometrix is a freely downloadable tool developed based on the science mapping package for the $\mathrm{R}$ programming language for detecting, quantifying, and visualizing the evolution of a research field [62].

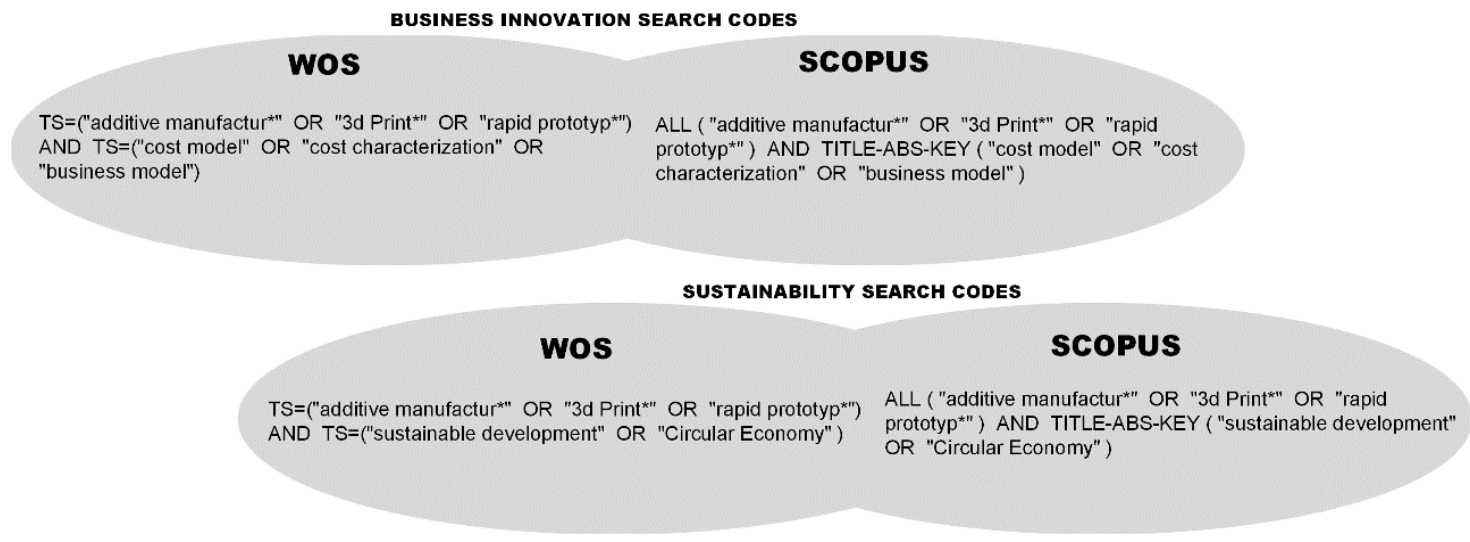

Figure 4. Specific search codes used for searching databases.

First, a general search was performed using the search string in both selected databases. Second, we removed duplicates and excluded the articles that did not satisfy the inclusion criteria I1, I2, and I3 already established. Finally, we reviewed the articles obtained previously by title, then by abstract, and then by full text. We selected the articles concerning sustainability and business innovation topics. In addition, we included the remaining articles for a qualitative synthesis for this research. The detailed process flow used to gather the information is shown in Figure 5.

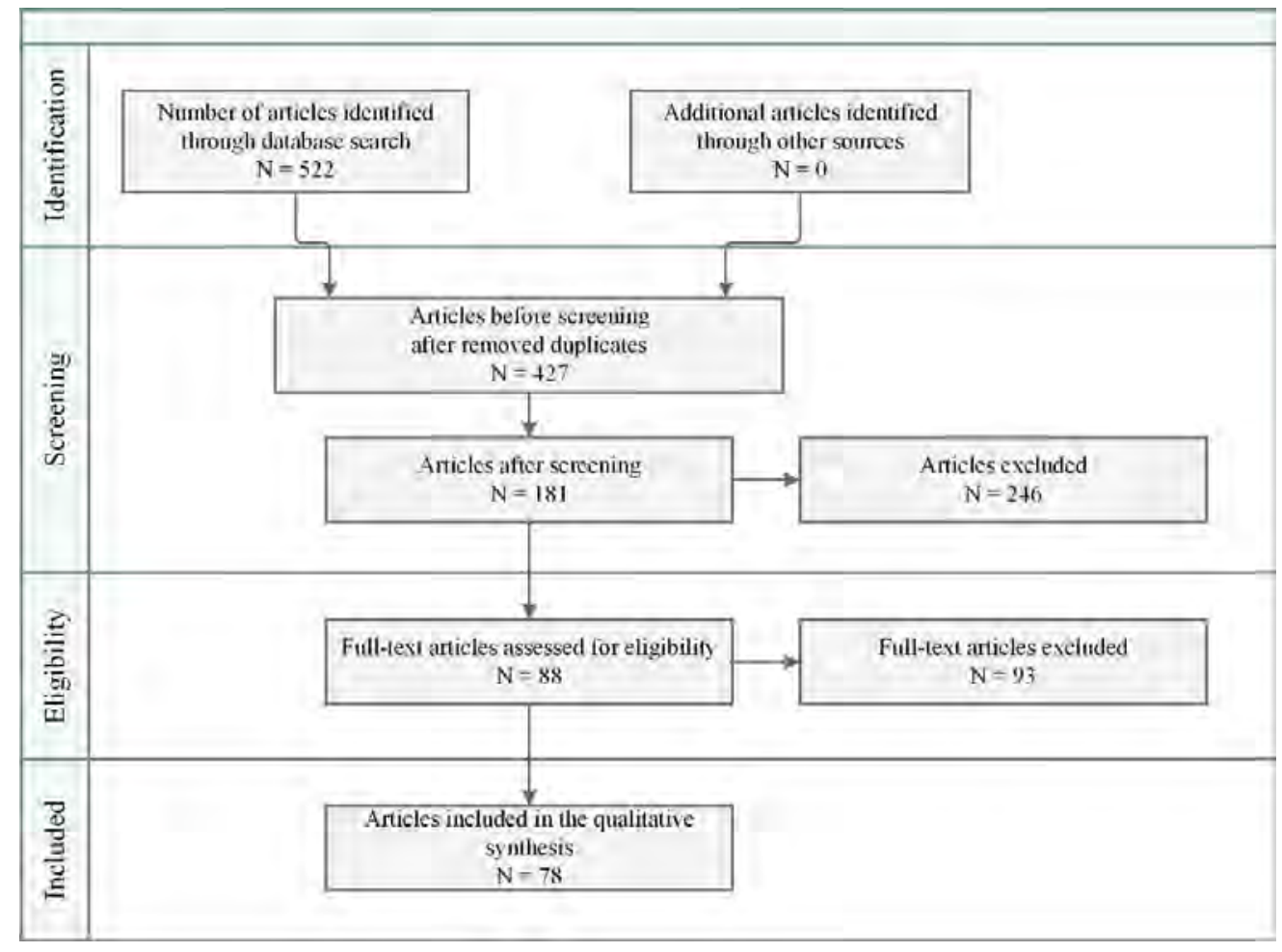

Figure 5. Flow diagram for systematic literature review. 


\section{Results}

\subsection{Bibliometric Findings}

The year-wise numbers of publications in both study areas are presented in Figure 6 (through February 2020). These numbers indicate the research trend in these topics and show that research productivity increased from 2015 onward. Note that studies on the sustainability area in AM were initially conducted in 2013. These studies involved the life-cycle economic analysis of open-source 3D printers [63]; further, the benefits of this technology were demonstrated in terms of the cost, time, and energy savings for personal use, and its sustainable development in terms of the payback time and return on investment. Notably, while several journals published literature on either of the two study areas, only six journals published literature on both areas (Table 1). From the data listed in Table 2, it is evident that the International Journal of Advanced Manufacturing Technology and Journal of Cleaner Production published the maximum number of papers on BI and sustainability, respectively. Both journals publish the most recent scientific literature on the two topics.

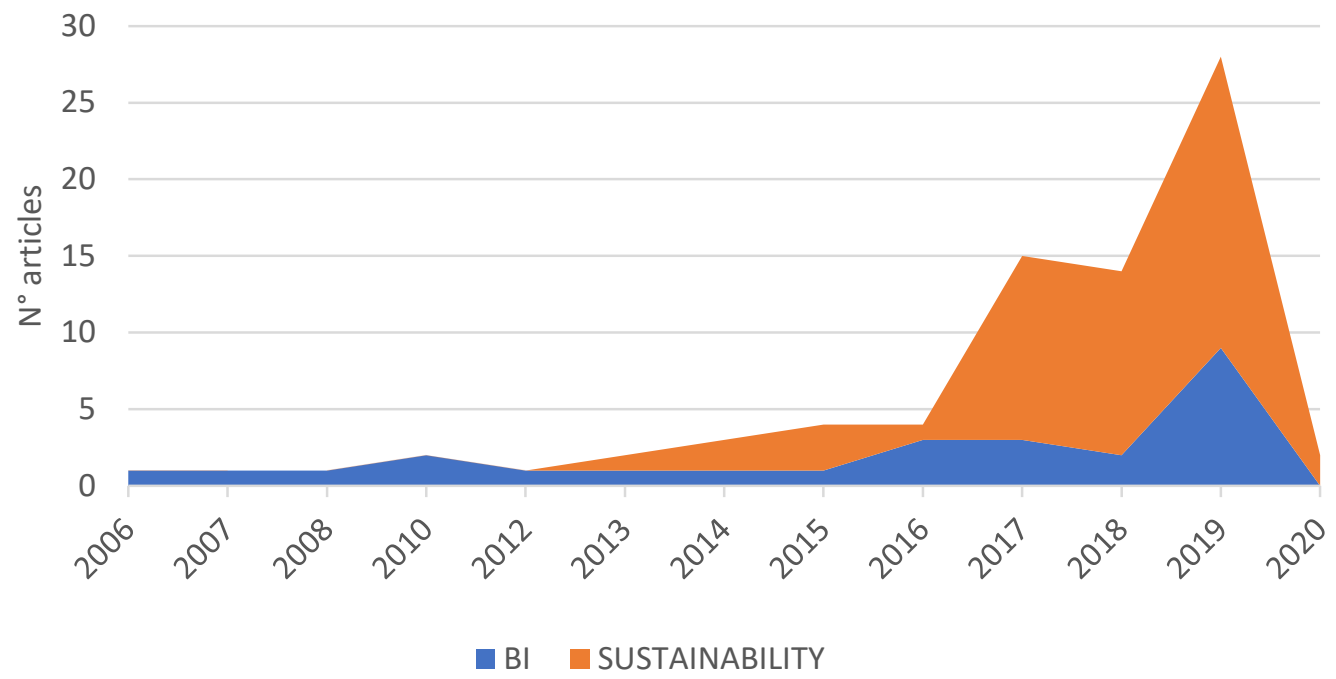

Figure 6. Year-wise literature production on business innovation and sustainability in additive manufacturing.

Table 1. List of journals publishing literature on both business innovation and sustainability in additive manufacturing (AM).

\begin{tabular}{ccc}
\hline Journals & BI & Sustainability \\
\hline Additive Manufacturing & 5 & 2 \\
International Journal of Advanced Manufacturing Technology & 3 & 2 \\
International Journal of Production Economics & 2 & 1 \\
Journal of Manufacturing Systems & 2 & 2 \\
Journal of Manufacturing Technology Management & 1 & 1 \\
Technological Forecasting and Social Change & 1 & 1 \\
\hline
\end{tabular}


Table 2. Names of journals along with the year and number of articles published on the two topics.

\begin{tabular}{|c|c|c|c|c|c|c|c|c|c|c|c|c|c|c|c|}
\hline \multirow{2}{*}{ Journal Name } & \multirow[t]{2}{*}{ Topic } & \multicolumn{14}{|c|}{ Number of Articles Published } \\
\hline & & 2006 & 2007 & 2008 & 2010 & 2012 & 2013 & 2014 & 2015 & 2016 & 2017 & 2018 & 2019 & 2020 & Total \\
\hline International Journal of Advanced Manufacturing Technology & Business Innovation & & & & & 1 & & & & 1 & 1 & & 2 & & 5 \\
\hline International Journal of Production Economics & & & & & 1 & & & & & & & 1 & 1 & & 3 \\
\hline Rapid Prototyping Journal & & & & & 1 & & 1 & & & & & 1 & & & 3 \\
\hline Journal of Manufacturing Technology Management & & & & & & & & & & & 1 & & 1 & & 2 \\
\hline Journal of Thermal Spray Technology & & & & & & & & 1 & & & & & 1 & & 2 \\
\hline $\begin{array}{l}\text { Proceedings of the Institution of Mechanical Engineers Part B-Journal of Engineering } \\
\text { Manufacture }\end{array}$ & & 1 & 1 & & & & & & & & & & & 2 & \\
\hline Technological Forecasting and Social Change & & & & & & & & & & 2 & & & & & 2 \\
\hline Additive Manufacturing & & & & & & & & & & & & & 1 & & 1 \\
\hline British Food Journal & & & & & & & & & & & 1 & & & & 1 \\
\hline Computers in Industry & & & & 1 & & & & & & & & & & & 1 \\
\hline Entrepreneurship Research Journal & & & & & & & & & 1 & & & & & & 1 \\
\hline Journal of Manufacturing Systems & & & & & & & & & & & & & 1 & & 1 \\
\hline Journal of Mechanical Science and Technology & & & & & & & & & & & & & 1 & & 1 \\
\hline Journal of Operations Management & & & & & & & & & & & & & 1 & & 1 \\
\hline & TOTAL: & 1 & 1 & 1 & 2 & 1 & 1 & 1 & 1 & 3 & 3 & 2 & 9 & & 26 \\
\hline Journal of Cleaner Production & Sustainability & & & & & & & & 1 & 1 & 3 & & 3 & 2 & 10 \\
\hline Journal of Industrial Ecology & & & & & & & & & & & 3 & & 1 & & 4 \\
\hline Materials & & & & & & & & & & & & 1 & 2 & & 3 \\
\hline Materials Today Communications & & & & & & & & & & & & 3 & & & 3 \\
\hline California Management Review & & & & & & & & & & & & 2 & & & 2 \\
\hline International Journal of Advanced Manufacturing Technology & & & & & & & & & & & 1 & & 1 & & 2 \\
\hline International Journal of Production Economics & & & & & & & & & & & & & 2 & & 2 \\
\hline Journal of Manufacturing Technology Management & & & & & & & & & & & & 1 & 1 & & 2 \\
\hline Polymer Testing & & & & & & & & 1 & 1 & & & & & & 2 \\
\hline ACS Omega & & & & & & & & & & & & 1 & & & 1 \\
\hline Additive Manufacturing & & & & & & & & & & & & & 1 & & 1 \\
\hline Angewandte Chemie - International Edition & & & & & & & & & & & 1 & & & & 1 \\
\hline Applied Sciences (Switzerland) & & & & & & & & & & & & & 1 & & 1 \\
\hline CIRP Annals & & & & & & & & & & & & & 1 & & 1 \\
\hline CIRP Journal of Manufacturing Science and Technology & & & & & & & & & & & & 1 & & & 1 \\
\hline Clean Technologies and Environmental Policy & & & & & & & & & 1 & & & & & & 1 \\
\hline Composites Part A: Applied Science and Manufacturing & & & & & & & & & & & 1 & & & & 1 \\
\hline Energy for Sustainable Development & & & & & & & & & & & 1 & & & & 1 \\
\hline Energy Policy & & & & & & & & 1 & & & & & & & 1 \\
\hline
\end{tabular}


Table 2. Cont

\begin{tabular}{|c|c|c|c|c|c|c|c|c|c|c|c|c|c|c|c|}
\hline \multirow{2}{*}{ Journal Name } & \multirow[t]{2}{*}{ Topic } & \multicolumn{14}{|c|}{ Number of Articles Published } \\
\hline & & 2006 & 2007 & 2008 & 2010 & 2012 & 2013 & 2014 & 2015 & 2016 & 2017 & 2018 & 2019 & 2020 & Total \\
\hline International Journal of Intelligent Systems & & & & & & & & & & & 1 & & & & 1 \\
\hline Journal of Manufacturing Systems & & & & & & & & & & & & 1 & & & 1 \\
\hline Journal of Medical Systems & & & & & & & & & & & & 1 & & & 1 \\
\hline Journal of Thermoplastic Composite Materials & & & & & & & & & & & & & 1 & & 1 \\
\hline Mechatronics & & & & & & & 1 & & & & & & & & 1 \\
\hline Polymers & & & & & & & & & & & & & 1 & & 1 \\
\hline Powder Technology & & & & & & & & & & & & & 1 & & 1 \\
\hline Processes & & & & & & & & & & & & & 1 & & 1 \\
\hline Resources, Conservation and Recycling & & & & & & & & & & & & 1 & & & 1 \\
\hline Sustainability & & & & & & & & & & & & & 1 & & 1 \\
\hline Technological Forecasting and Social Change & & & & & & & & & & & 1 & & & & 1 \\
\hline Virtual and Physical Prototyping & & & & & & & & & & & & & 1 & & 1 \\
\hline & TOTAL: & & & & & & 1 & 2 & 3 & 1 & 12 & 12 & 19 & 2 & 52 \\
\hline
\end{tabular}


On the BI topic, the International Journal of Advanced Manufacturing Technology published five articles that met the inclusion criteria described earlier. On the sustainability topic, the Journal of Cleaner Production is the most relevant, with 10 articles over the past 5 years. Figure 7 exhibits the keywords co-occurrences for BI, as provided by the Bibliometrix package. The most common keyword is additive manufacturing, which is related to the ASTM Standard in Terminology for AM [64], the terminology commonly used in connection with the standard. The latest keyword used for BI is "cost optimization," in relation to cost optimization in the laser-type AM, cost optimization comparing mechanical properties of a determinate product, and cost optimization for deposition efficiency. For BI keywords, there are three main clusters whose principal terms are "design," "additives/metals," and "cost-benefit analysis." Based on research keywords used recently, the evolution of BI is moving in the direction of the cost optimization of 3D printing applications, performance, and business model proposals.

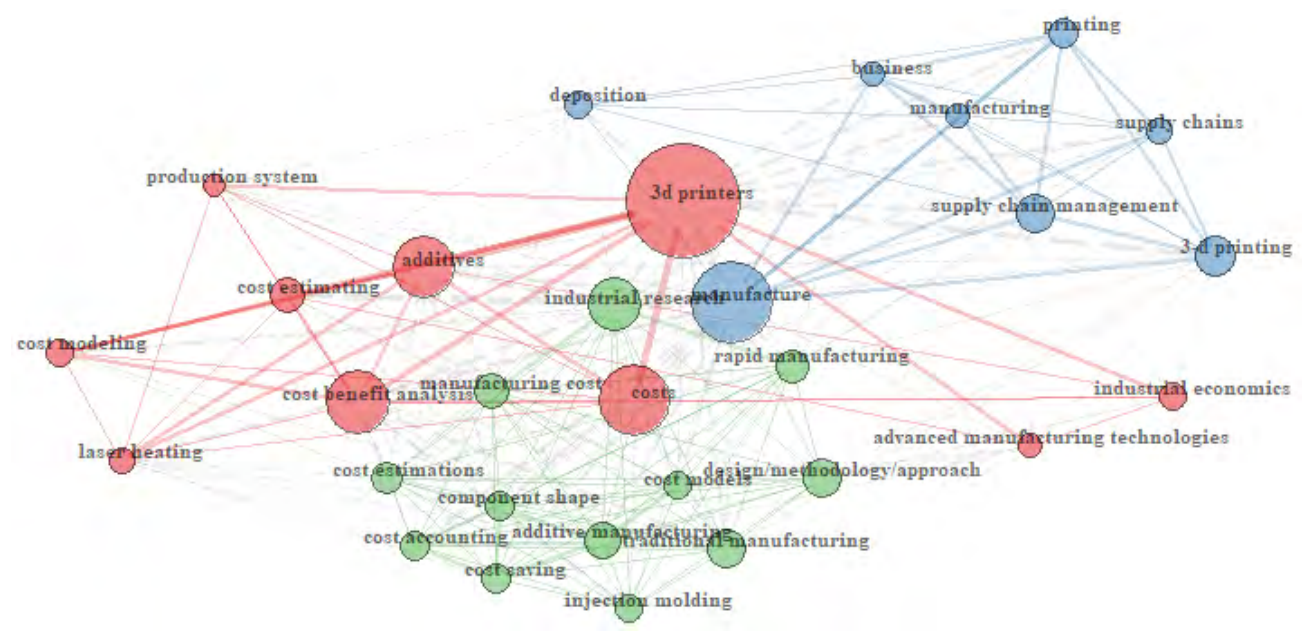

Figure 7. Keyword co-occurrences for BI.

The authorship pattern showed that the average number of authors per article in BI articles was three. Among the 78 shortlisted articles, there was only one single-author article. The most productive authors in the BI domain are listed in Figure 8. Richard Hague published two articles in co-authorship with Massimiliano Ruffo. One paper, by Eleonora Atzeni, topped the list of the 10 most cited articles (Table 3).

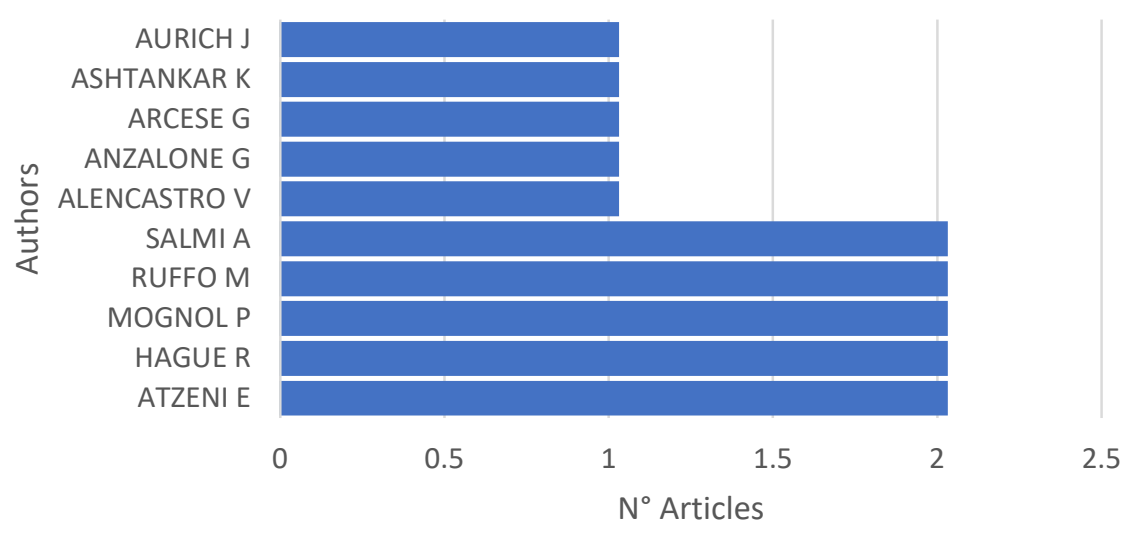

Figure 8. Most productive authors in business innovation domain. 
Table 3. Top 10 most cited articles on business innovation.

\begin{tabular}{cccc}
\hline No. & Article & Total Citations (tc) & Tc/Year \\
\hline 1 & {$[65]$} & 277 & 30.78 \\
2 & {$[66]$} & 137 & 9.13 \\
3 & {$[38]$} & 110 & 10.00 \\
4 & {$[3]$} & 103 & 20.60 \\
5 & {$[67]$} & 71 & 8.88 \\
6 & {$[68]$} & 63 & 4.50 \\
7 & {$[69]$} & 57 & 4.38 \\
8 & {$[70]$} & 48 & 9.60 \\
9 & {$[71]$} & 33 & 3.00 \\
10 & {$[28]$} & 25 & 5.00 \\
\hline
\end{tabular}

Our findings on research productivity in the BI domain indicate that at least $69 \%$ of the articles were published during the past 5 years, which shows an increasing interest in this domain of AM.

In the sustainability field, "additive manufacturing" is the most used keyword. The latest keywords include "filament," "extruder," "waste plastic," "recycling," and "large-scale." The keyword "filament" is related to RepRap, open-source, CE, and polymers. "Extruder" is related to design, distributed manufacturing, and polyethylene. "Waste plastic," "recycling," and "large scale" are other common keywords related to $\mathrm{CE}$, polymers, and distributed manufacturing. Based on the most recent research keywords, research in sustainability is being directed towards the study of raw materials from recycled materials and polymers to facilitate the processes for the implementation of $\mathrm{CE}$. Three clusters in keyword co-occurrence can be distinguished from the R Bibliometrix analysis tool (Figure 9). The first cluster (blue) it is related to the sustainable development of AM in respect of two technologies: fused deposition modeling and selective laser sintering, where energy efficiency and material recycling are being actively studied. The second cluster is related to metal AM technologies. The principal keywords for these technologies are "powder bed fusion" and "laser beam melting sintering" methods for metal parts and their relationship with the sustainability of AM through energy utilization analyses, life cycle analyses, and comparative studies with various materials. The third cluster includes keywords relating to the ecological and environmental impacts of AM.

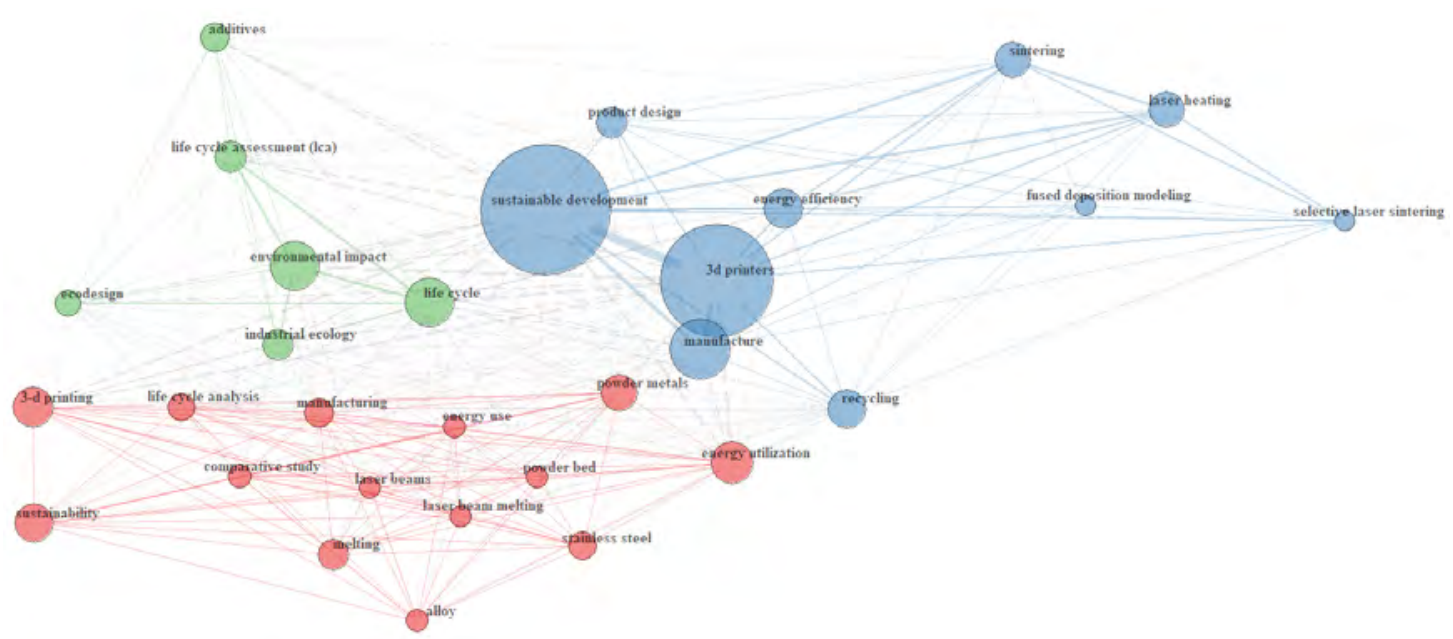

Figure 9. Keyword co-occurrences in sustainability domain. 
Among the 52 identified articles, one author wrote a single-author article and 193 authors contributed to multi-authored articles. On an average, there were 3.73 authors per article. While $4 \%$ of the identified articles were reviews related to CE and the environmental impact of AM, the rest were original articles. Finally, among the top ten most productive authors in the literature on sustainability (Figure 10), we may mention Joshua Pearce and Aubrey Woern, who had six and three articles, respectively. From the most cited reference point of view, Malte Glebler had 246 global citations for an original article related to qualitative results of sustainability evaluation of 3D printing (Table 4).

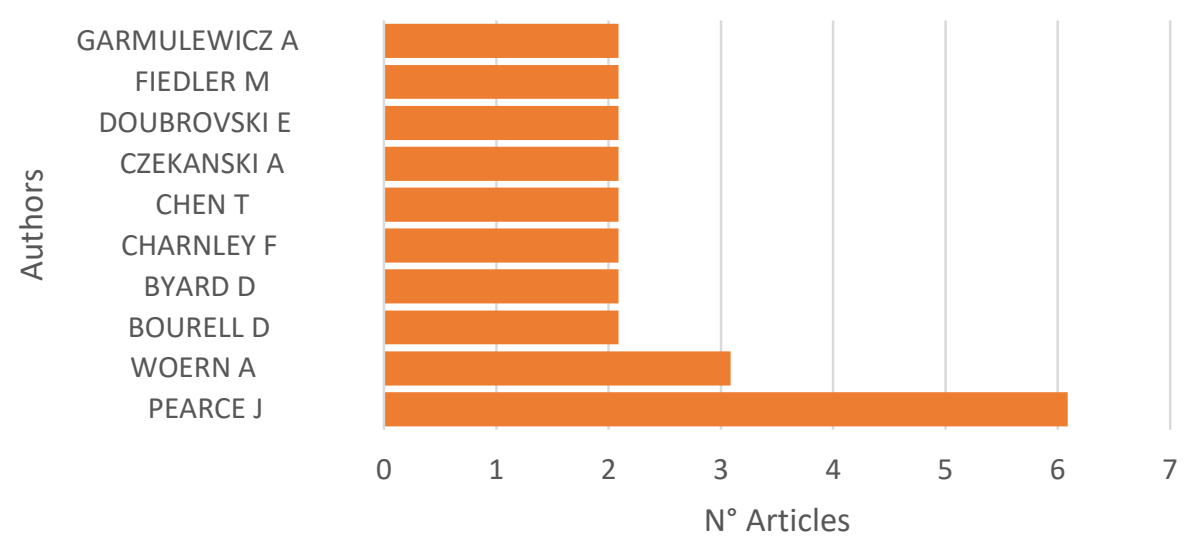

Figure 10. Most productive authors on sustainability.

Table 4. Top 10 most cited articles on sustainability.

\begin{tabular}{cccc}
\hline No. & Article & Total Citations & Tc/Year \\
\hline 1 & {$[72]$} & 246 & 35.143 \\
2 & {$[63]$} & 185 & 23.125 \\
3 & {$[9]$} & 132 & 22 \\
4 & {$[73]$} & 82 & 20.5 \\
5 & {$[74]$} & 52 & 13 \\
6 & {$[75]$} & 49 & 9.8 \\
7 & {$[76]$} & 39 & 9.75 \\
8 & {$[77]$} & 29 & 7.25 \\
9 & {$[78]$} & 28 & 9.333 \\
10 & {$[32]$} & 28 & 9.333 \\
\hline
\end{tabular}

Based on our thematic systematic review, $86.79 \%$ of the articles are from the past 4 years, including the initial months of 2020, and are available online.

Based on the collaboration diagram presented in Figure 11, there were no remarkable collaborations among countries on BI studies. In contrast, in sustainability studies related to AM, the United Kingdom and the USA were the principal countries that collaborated. Notably, the European countries comprised almost half of all countries that published sustainability studies and collaborated with each other, whereas only two Latin American countries published sustainability studies and collaborated with each other. 
(a)

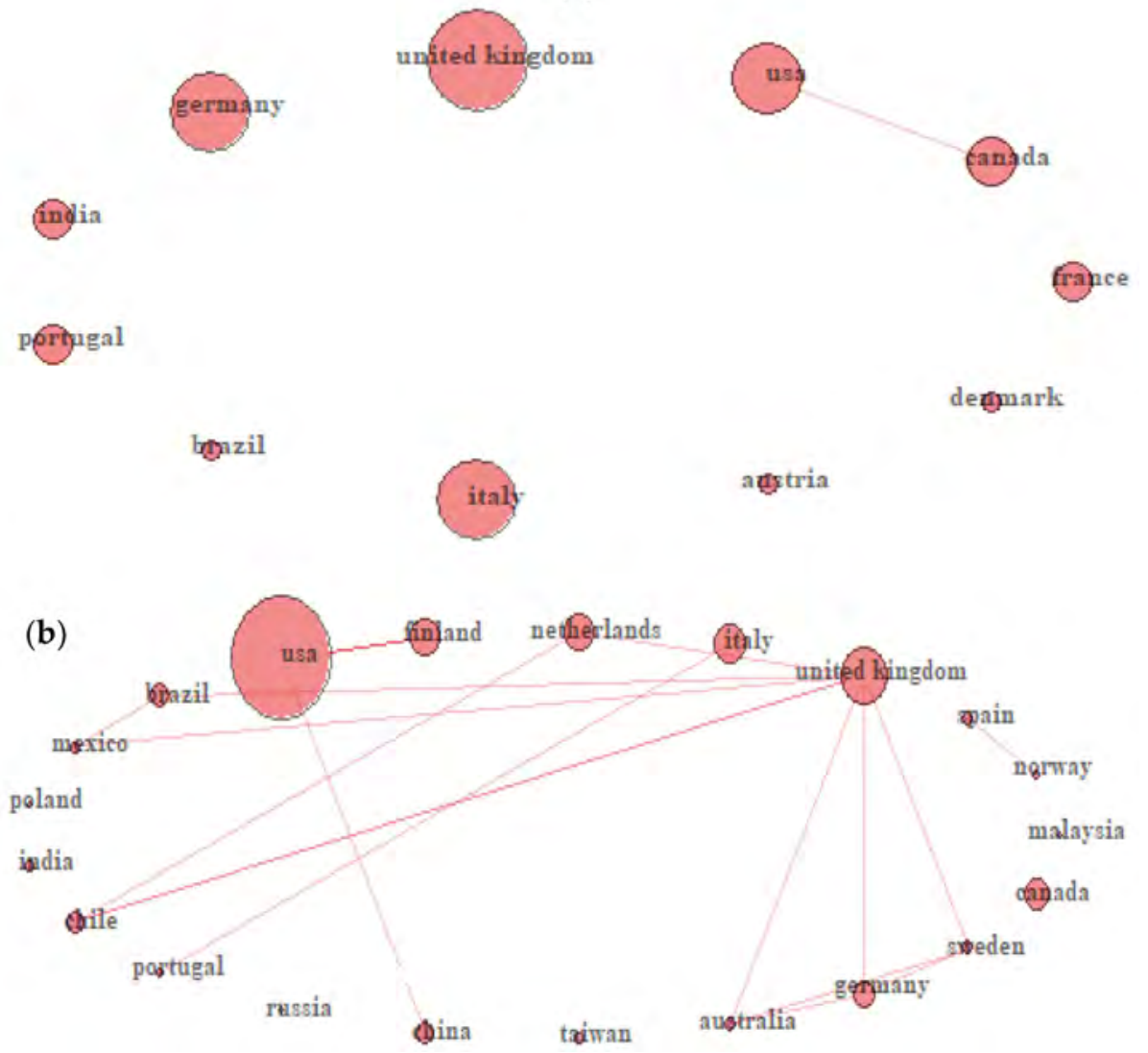

Figure 11. Country collaborations for (a) business innovation and (b) sustainability studies.

Among the most productive countries (Figure 12), Italy and the USA occupy the two top positions in both study areas. Italy, with a $26 \%$ share, leads the scientific literature production on BI studies and is followed by the USA in second place, with a $16 \%$ share. The USA, with a $21 \%$ share, leads the scientific literature production on sustainability, and is followed by Italy in second position, with a $12 \%$ share. Furthermore, combining the top ten countries contributing to both study areas in a Pareto analysis, $80 \%$ of the scientific research comes from the USA, Italy, the United Kingdom, the Netherlands, Canada, Brazil, China, and France (Figure 13).

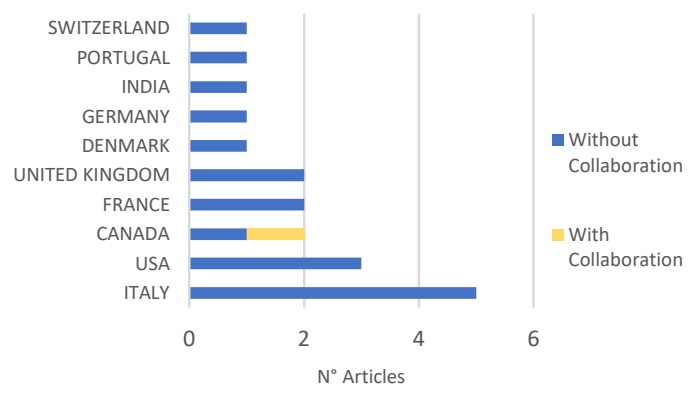

(a)

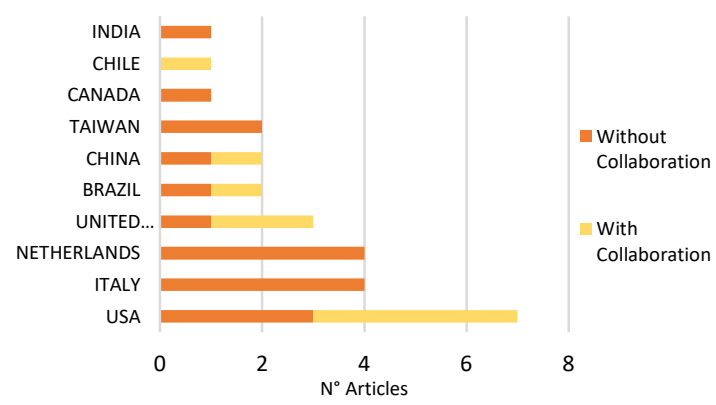

(b)

Figure 12. Most productive countries in terms of literature production on (a) business innovation and (b) sustainability in additive manufacturing. 


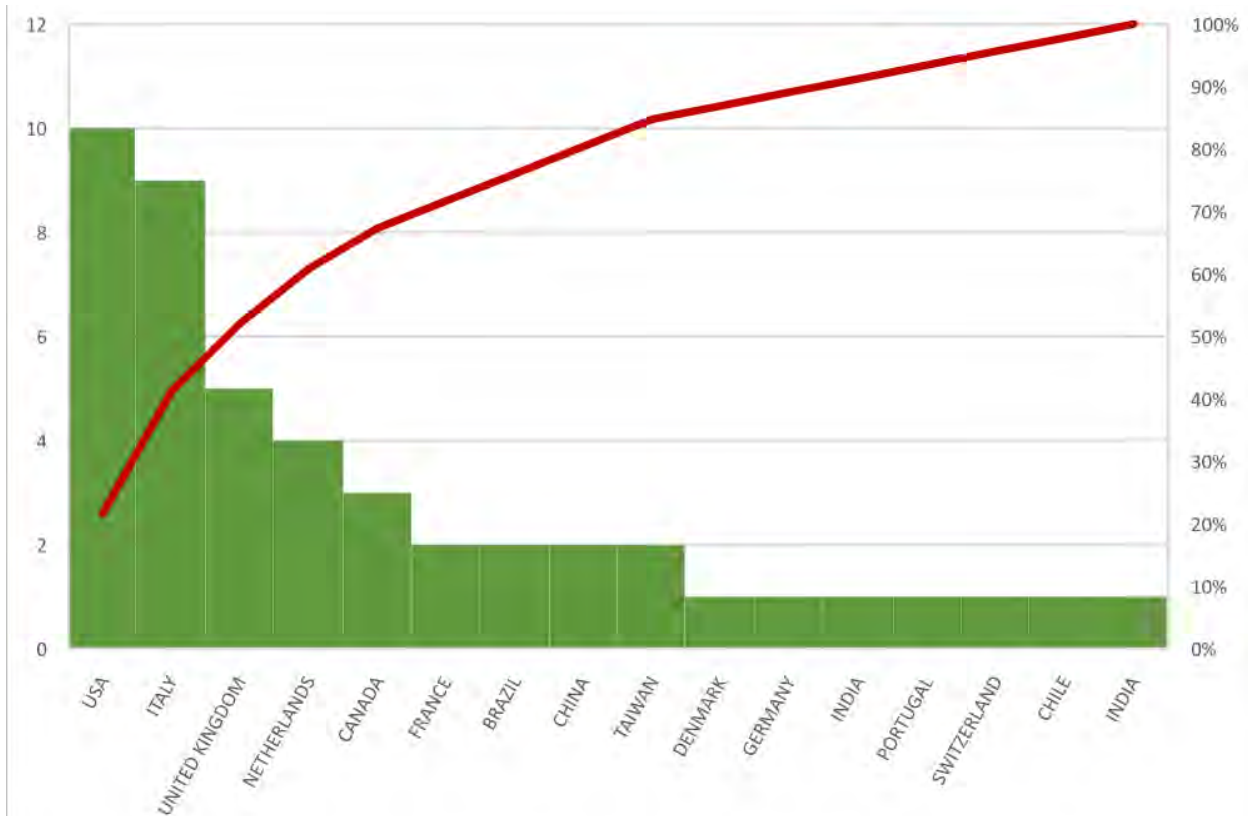

Figure 13. Pareto analysis of country-wise literature production in both study areas.

\subsection{Recent Developments in AM}

\subsubsection{Developments in BI}

It is interesting to note that $\mathrm{BI}$ studies in recent years range from cost model characterization to supply-chain and operation-cost adaptation (Figure 14). Based on this systematic literature review, we found that the cost characterization was oriented principally toward two types of AM: polymer raw material process SLS (selective laser sintering) and FDM. To the best of our knowledge, there is just one research paper on cost characterization using the FDM technology [40]. However, there are several articles on cost characterization using the SLS technology (Table 5), originating mostly from [79].

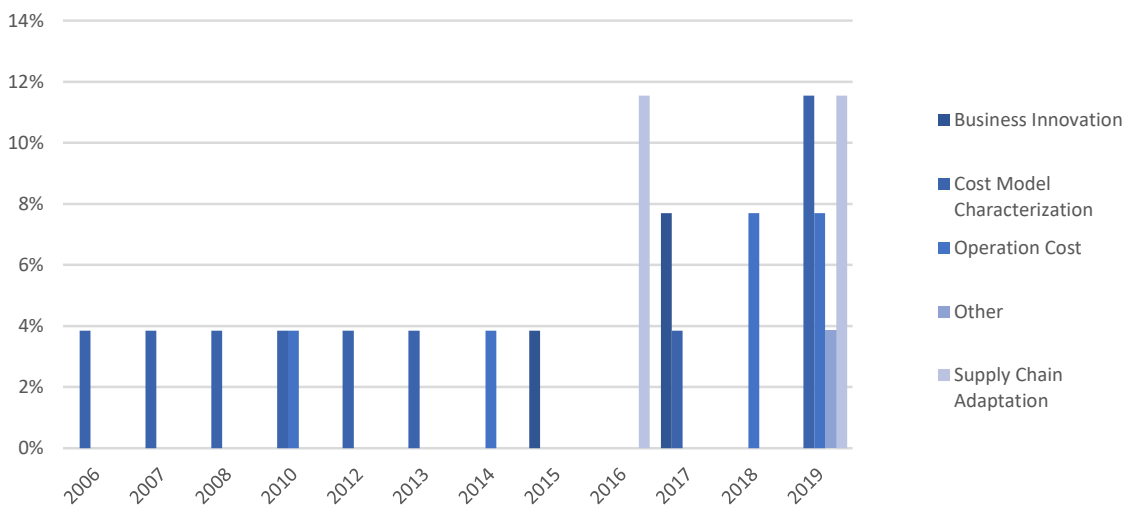

Figure 14. Year-wise percentage of articles on some specific topics. 
Table 5. Author contributions to cost characterization.

\begin{tabular}{|c|c|c|c|c|}
\hline Author(s) & Year & Contribution/Assumption & AM Process & Reference \\
\hline $\begin{array}{l}\text { Neil Hopkinson and Phill } \\
\text { Dickens [40] }\end{array}$ & 2003 & $\begin{array}{l}\text { Cost comparison of injection molding } \\
\text { with layer manufacturing process. Cost } \\
\text { included: machine, labor, and material. }\end{array}$ & $\begin{array}{l}\text { SLA } \\
\text { FDM } \\
\text { SLS }\end{array}$ & $\begin{array}{l}38] \\
{[67]} \\
{[80]} \\
{[81]} \\
{[82]}\end{array}$ \\
\hline Massimiliano Ruffo et al. [66] & 2006 & $\begin{array}{c}\text { Cost based on lifecycle costing, cost } \\
\text { objective, and full costing. Assuming } \\
100 \mathrm{~h} \text { machine working time per week } \\
\text { over } 50 \text { weeks/year. }\end{array}$ & SLS & $\begin{array}{l}{[79]} \\
{[66]} \\
{[68]} \\
{[82]}\end{array}$ \\
\hline Ian Campbell [83] & 2008 & $\begin{array}{l}\text { 2D schema time estimator to make a } \\
\text { quotation before the STL file. The } \\
\text { construction time of a single piece. }\end{array}$ & SLA & \\
\hline Eleonora Atzeni et al. [38] & 2010 & $\begin{array}{l}\text { AM cost characterization based on } \\
\text { injection molding cost elements. The } \\
\text { same piece could be fabricated by } \\
\text { injection molding and AM. }\end{array}$ & SLS & $\begin{array}{l}{[5]} \\
{[67]} \\
{[38]} \\
{[82]}\end{array}$ \\
\hline Lukas Rickenbacher et al. [67] & 2013 & $\begin{array}{l}\text { Each part cost model estimator for a } \\
\text { mixed build including pre- and post- } \\
\text { processing. Same variables as in the } \\
1998 \text { Paul Alexander cost model. }\end{array}$ & SLM & $\begin{array}{l}{[81]} \\
{[82]}\end{array}$ \\
\hline Martin Baumers et al. [80] & 2016 & $\begin{array}{l}\text { Cost structure measurement model } \\
\text { adapted from Ruffo and Hague, (2007). } \\
\text { Raw material cost and energy } \\
\text { consumption are considered as direct } \\
\text { cost for the evaluation of both } \\
\text { AM technologies. }\end{array}$ & $\begin{array}{l}\text { EBM } \\
\text { Direct Metal } \\
\text { Laser } \\
\text { Sintering } \\
\text { (DMLS) }\end{array}$ & [82] \\
\hline Marcello Fera et al. [81] & 2017 & $\begin{array}{l}\text { Cost evaluation of relevant AM } \\
\text { technologies when integrated with a } \\
\text { general production process. Five } \\
\text { generic process steps were assumed: } \\
\text { preparation, build job, setup, building, } \\
\text { and removal. }\end{array}$ & $\begin{array}{l}\text { SLA } \\
\text { SLS } \\
\text { EBM }\end{array}$ & [82] \\
\hline Yiran Yang and Lin Li [82] & 2018 & $\begin{array}{l}\text { Cost model to evaluate the cost } \\
\text { performance of simultaneous } \\
\text { production with non-mixed and mixed } \\
\text { geometries. Nonuniform energy cost } \\
\text { per part for various geometries and } \\
\text { some constants in formulation for an } \\
\text { optimization problem. }\end{array}$ & $\begin{array}{l}\text { Mask image } \\
\text { projection } \\
\text { SLA }\end{array}$ & \\
\hline
\end{tabular}

The cost characterization proposed by Massimiliano Ruffo for the SLS technology (1) is oriented to calculate the indirect cost associated with the construction time $\left(t_{\mathrm{B}}\right)$ and the direct cost associated with the used material in the construction $\left(\mathrm{m}_{\mathrm{B}}\right)$ :

$$
\operatorname{Cost}_{\mathrm{B}}=\operatorname{Cost}\left(\mathrm{t}_{\mathrm{B}}\right)+\operatorname{Cost}\left(\mathrm{m}_{\mathrm{B}}\right)
$$

This cost characterization model was proposed for low-to-medium-production sizes. Later in 2007 [68], a change was proposed to this model based on the various production scenarios for the production of a single type of part. Massimiliano Ruffo and Richard Hague based the cost characterization on the Hopkinson-Dickenson cost model [40], which was principally designed to compare the costs of producing a part using AM techniques (SLA, FDM, and SLS) and injection molding for selected geometries and different quantities.

A study in 2010 compared AM and injection molding and interrelated the flexibility of redesigning AM technologies and cost estimation [38] and introduced the formal concept of design for rapid manufacturing. Dilip Sahebrao followed the step-in cost characterization but considered other constraints such as the total cost of preparation. In this first attempt, the author established the cost-determining factors particularly for the FDM technology to obtain the optimal part orientation and the value of parameters resulting in the minimum total cost [84]. In 2013, a new cost model 
was formulated for the SLM (selective laser melting) process, which included all required preand post-processing steps and considered part orientation and build cost based on the model by Alexander et al. [85]. Finally, in 2018, Yang and Li [82] proposed a new cost model for complex and simultaneous production for mixed geometries using the SLA process and formulated a manufacturing cost optimization problem considering decision variables such as the layer thickness and surface stratification angle. Researchers established polymers as raw materials for cost characterization because of the ease to compare with traditional processes such as injection molding. Various authors and their contributions are presented in Table 5. The cost characterization proposed by Hopkinson and Dickens [40], Ruffo, M. [66], Rickenbacher, L. [67], and Baumers, M. [80] did not consider the operational costs in a manufacturing system or in the implementation of industry 4.0, whereas Atzeni, E. [38], Fera, M. [81], and Yang and Li [82] proposed a cost model considering some operational costs for AM implementation. To the best of our knowledge, authors have not considered in cost evaluation the possibility of a redistributed manufacturing $[3,4]$ that may reduce supply chain and inventory costs; one of the key factors of AM implementation in Industry 4.0 context.

Regarding the business model, there is an innovative perspective because AM technologies offer the freedom to customize. Bogers et al. [3] highlighted some considerations from a business model perspective to shift from a manufacturer- to consumer-centric value logic, giving some comparisons between AM technologies for consumer goods manufacturers, and formulated an idea for client-oriented decentralized supply chain. Rayna and Striukova, [4], using the key components of business models, established a forecast on how 3D printing can change business model innovation and discussed its evolution from rapid prototyping and direct manufacturing to home fabrication. Jia et al. [70] explored a supply-chain-centric business model in 3D chocolate printing and simulated a business model on customer preferences using the ExtedSim software. Laplume et al. [28] established the availability of 3D printing business models considering some parameters to evaluate the margin advantage, net present value, and the return on investment from open-source 3D printers. From another perspective, Holzmann et al. [27] gathered and analyzed data from eight user entrepreneurs in Europe and North America, not only resulting in specific information on the customer and market type from a managerial point of view but also identifying some issues that possibly affect the formulation of public policies. Analyzing mature markets (traditional companies), Flammini et al. [86] proposed a framework based on the traditional business model considering emerging technologies such as AM (3D printing) and affirmed that it is possible to use more than one business model simultaneously. More recently, Mattos Nascimento et al. [36] explored how emerging technologies such as AM, from Industry 4.0, can be integrated with CE. The principal outcome of their study was the recommendation of a circular model to reuse some Industry 4.0 waste, including AM to support circular economy. Research in business innovation has considered $\mathrm{AM}$ as a tool to be implemented by entrepreneurs in new business models [28], as an innovative tool proposed for changes in traditional business models [86], and more recently as business proposals based on CE strategies [36] for its capabilities in customization, low waste production, and free-form build.

\subsubsection{Developments in Sustainability}

We classified the developments in sustainability as the developments in sustainable processes, creation or usability of recycled materials for various types of AM technologies, and creation of sustainable technologies. After the papers were screened and analyzed, we found that at least $52 \%$ of them pertained to the development of sustainable processes, $29 \%$ to sustainable technology, and $19 \%$ to recycled materials (Figure 15). 


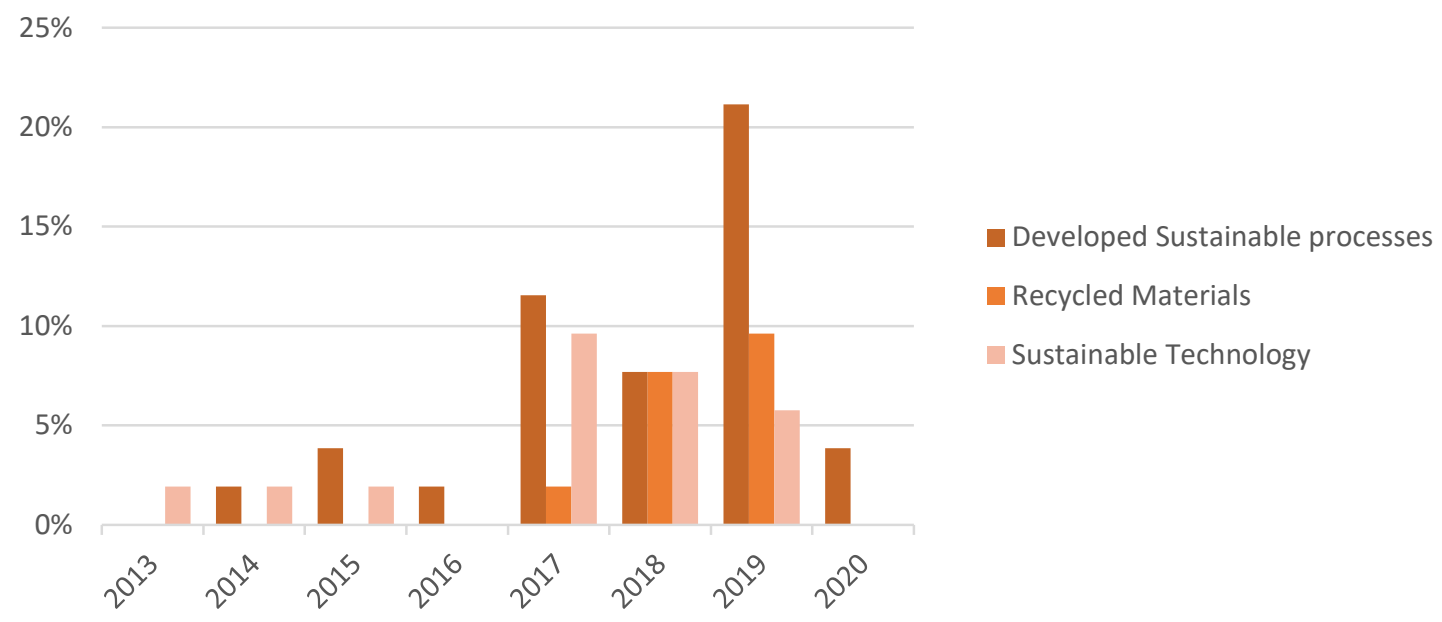

Figure 15. Classification of articles based on development aspects in sustainability.

$\mathrm{AM}$, as a relatively novel technology, has high potential in production cost reduction, is amenable to customization, and can reduce $\mathrm{CO}_{2}$ emission from industrial activity [72]. In recent years, from a sustainability point of view, research in AM has focused in the utilization of recycled materials and economic model implementations such as the $\mathrm{CE}$ and social movements to reduce $\mathrm{CO}_{2}$ emissions from industrialization. In Table 6, we present a synopsis of the materials considered for recycling in the AM process. Research on the sustainable economic model in the AM technology was also considered. CE is based on a philosophical concept of the creation-a schema that includes regenerating natural systems, maintaining materials in use and designing products while minimizing waste and pollution [87]. Some authors have seen AM as an enabler for the development of $\mathrm{CE}$ and its potential for the product design [88], business modeling to facilitate CE in the Industry 4.0 context [36], use of recycled plastic in the manufacturing process to enhance $\mathrm{CE}[32,89]$, and repair, refurbish, and remanufacture of metal components to return its value during its life cycle in the CE context [90].

Table 6. Recycling materials for additive manufacturing processes proposed by various authors.

\begin{tabular}{|c|c|c|c|}
\hline Author (s) & Recycling Material & Demostrated for & Application \\
\hline $\begin{array}{l}\text { Fedor Kucherov et al. } \\
\text { [76] }\end{array}$ & $\begin{array}{c}\text { Biomass-derived red } \\
\text { polyethylene-2,5-furandicarboxylate (PEF) }\end{array}$ & $\begin{array}{l}\text { Fused deposition } \\
\text { modeling }\end{array}$ & $\begin{array}{l}\text { Better properties rather than the } \\
\text { available materials for FDM. High } \\
\text { thermal stability and low } \\
\text { temperature, which are necessary } \\
\text { for extrusion. }\end{array}$ \\
\hline Aubrey Woern et al. [91] & $\begin{array}{l}\text { Virgin polylactic acid (PLA), acrylonitrile } \\
\text { butadiene styrene (ABS), polyethylene } \\
\text { terephthalate (PET) and polypropylene (PP) }\end{array}$ & $\begin{array}{l}\text { Fused particle fabrication } \\
\text { Gigabot } X^{1}\end{array}$ & $\begin{array}{l}\text { To prove the usability of a wide } \\
\text { range of recycled polymer materials } \\
\text { with minimal post processing. }\end{array}$ \\
\hline $\begin{array}{c}\text { Joanna } \\
\text { Paciorek-Sadowska et al. } \\
\text { [92] }\end{array}$ & Eco-polyol based on polylactide (PLA) & $\begin{array}{l}\text { Recycling of AM } \\
\text { technology waste }\end{array}$ & $\begin{array}{l}\text { Fast, cheap, and ecological } \\
\text { management of polylactide waste } \\
\text { with possible reuse. }\end{array}$ \\
\hline Matthew Reich et al. [93] & Recycled polycarbonate & $\begin{array}{l}\text { Stiffness and mechanical } \\
\text { properties }\end{array}$ & Extrusion material for FDM \\
\hline
\end{tabular}

${ }^{1}$ Fused particle fabrication machine.

During the past 5 years, the developments in sustainable processes have been focused on the life-cycle assessment of AM manufactured products considering energy consumption [19,75,94-97], environmental impact and production costs [98,99], and remanufacturing and refurbishing of metal parts $[20,100,101]$ (see Table 7). 
Table 7. Recent developments on sustainable processes in additive manufacturing technologies.

\begin{tabular}{|c|c|c|c|c|}
\hline Author (s) & Year & Type of Process & Demonstrated for & Application \\
\hline Jian Qin et al. [19] & 2020 & $\begin{array}{l}\text { Energy } \\
\text { consumption } \\
\text { predictor }\end{array}$ & SLS & $\begin{array}{l}\text { Deep learning-driven } \\
\text { particle swarm } \\
\text { optimization to optimize } \\
\text { energy utility. }\end{array}$ \\
\hline Jinghua Xu et al. [97] & 2020 & $\begin{array}{l}\text { Energy efficiency } \\
\text { optimization }\end{array}$ & FDM & $\begin{array}{l}\text { 3DP energy optimization } \\
\text { based on adaptative } \\
\text { multi-layer } \\
\text { customization } \\
\text { considering material and } \\
\text { greenhouse gas } \\
\text { emissions }\end{array}$ \\
\hline $\begin{array}{l}\text { Paolo Priarone et al. } \\
\text { [99] }\end{array}$ & 2019 & $\begin{array}{c}\text { Framework for } \\
\text { cases in which AM } \\
\text { can substitute } \\
\text { machining } \\
\text { processes }\end{array}$ & $\begin{array}{l}\text { Wire arc additive } \\
\text { manufacturing }\end{array}$ & $\begin{array}{l}\text { Framework that } \\
\text { considers cost, } \\
\text { manufacturing times, } \\
\text { energy demand, and } \\
\text { carbon footprint and in } \\
\text { which machining can be } \\
\text { replaced with AM } \\
\text { process. }\end{array}$ \\
\hline $\begin{array}{c}\text { Abdollah Saboori et al. } \\
\text { [101] }\end{array}$ & 2019 & $\begin{array}{l}\text { Repair and } \\
\text { restoration of metal } \\
\text { parts }\end{array}$ & $\begin{array}{l}\text { Direct energy } \\
\text { deposition }\end{array}$ & $\begin{array}{l}\text { Aerospace and } \\
\text { automotive }\end{array}$ \\
\hline Chris Turner et al. [20] & 2019 & Supply chain & $\begin{array}{l}\text { Can be applied } \\
\text { with any AM } \\
\text { technology }\end{array}$ & $\begin{array}{l}\text { Redistributed } \\
\text { manufacturing closing } \\
\text { the loop between } \\
\text { customer and factories. }\end{array}$ \\
\hline Sheng Yang et al. [102] & 2018 & $\begin{array}{l}\text { Assembly design } \\
\text { and part } \\
\text { consolidation }\end{array}$ & SLM & $\begin{array}{l}\text { LCA proposed to } \\
\text { analyze of the } \\
\text { environmental } \\
\text { performance of assembly } \\
\text { operations plus part } \\
\text { consolidation via AM }\end{array}$ \\
\hline $\begin{array}{c}\text { Tobias Kamps et al. } \\
\text { [95] }\end{array}$ & 2018 & $\begin{array}{c}\text { Gear } \\
\text { manufacturing }\end{array}$ & LBM & $\begin{array}{l}\text { Life-cycle assessment of } \\
\text { AM implementation for } \\
\text { gear manufacturing } \\
\text { enterprises, considering } \\
\text { cost and energy } \\
\text { efficiency. }\end{array}$ \\
\hline Justin Bours et al. [98] & 2017 & $\begin{array}{l}\text { Raw material } \\
\text { evaluation }\end{array}$ & FDM PBF & $\begin{array}{l}\text { Life-cycle assessment } \\
\text { considering hazardous } \\
\text { implication in material } \\
\text { selection and } \\
\text { environmental impact. }\end{array}$ \\
\hline Yiran Yang et al. [82] & 2018 & $\begin{array}{l}\text { Energy } \\
\text { consumption } \\
\text { predictor }\end{array}$ & SLA & $\begin{array}{l}\text { Mathematical model for } \\
\text { energy consumption in } \\
\text { SLA AM technology } \\
\text { considering various } \\
\text { parameters and their } \\
\text { potential interaction. }\end{array}$ \\
\hline $\begin{array}{l}\text { Anoop Verma and } \\
\text { Rahul Rai [103] }\end{array}$ & 2017 & $\begin{array}{l}\text { Energy } \\
\text { consumption and } \\
\text { material wastage }\end{array}$ & SLS & $\begin{array}{l}\text { For sustainability } \\
\text { analysis and } \\
\text { optimization of } \\
\text { parameters. }\end{array}$ \\
\hline
\end{tabular}


Table 7. Cont.

\begin{tabular}{|c|c|c|c|c|}
\hline Author (s) & Year & Type of Process & Demonstrated for & Application \\
\hline $\begin{array}{c}\text { Osiris Canciglieri et al. } \\
\text { [104] }\end{array}$ & 2015 & $\begin{array}{l}\text { Prioritization for } \\
\text { sustainable AM } \\
\text { prototyping } \\
\text { technologies. }\end{array}$ & SLS FDM & $\begin{array}{c}\text { Proposed matrix to } \\
\text { consider environmental } \\
\text { and sustainable features } \\
\text { in the design } \\
\text { decision-making. }\end{array}$ \\
\hline
\end{tabular}

AM entails a huge advance in sustainability studies, from the improvements in refurbishment and remanufacturing processes $[20,101,102]$ to the impact in production systems such as energy consumption [19,94-98], the use of recycled raw materials [32,89], and the improvements which imply AM implementation for a CE strategy [88]. For Industry 4.0, AM studies in sustainability provide an opportunity for an environmentally sustainable manufacturing adaptation despite the high cost of AM implementation cost in a manufacturing environment. Moreover, various studies identified the benefits of AM implementation through a life-cycle assessment of AM manufactured products considering energy consumption [19,94-98], environmental impact, and production costs [99,100].

\section{Discussion}

Three-dimensional printing, also known as AM in the Industry 4.0 context, may offer potential benefits by way of its design freedom [105] and capability to revolutionize industry in terms of sustainability [106]. For production and operation management, the integration of AM technologies can facilitate business process management and help to predict, optimize, and automate the manufacturing process in the Industry 4.0 ecosystem [47]. The multiple cost model based on the standalone implementation of AM [38,40,66,67], integration in a traditional manufacturing environment [81], and others for the redistribution of large manufacturing environments to local factories [107] can enable smart production systems. The proposed AM technology business models are based on the fast production of multiple parts [27], energy consumption and wastage management [36], and a solution for refurbishing of metal parts $[100,101]$. Traditional machining systems, such as the computer numerical control milling, have been compared with $\mathrm{AM}[6,94,96]$ in terms of the energy efficiency, $\mathrm{CO}_{2}$ emissions, and relative costs of low- to medium-production batches [66]. Various authors proposed the characterization of the AM cost model for a standalone production or various geometries in a build $[40,66,67,80]$. However, for the implementation in a traditional manufacturing environment, to the best of our knowledge, cost evaluation has not been considered for a redistributed manufacturing model $[3,4]$ that may reduce supply chain and inventory costs all together with an environmental sustainability improvement. Despite the AM cost, various studies have supported the AM implementation cost and environmental sustainability through a life-cycle assessment.

Recent studies have focused on the analysis of AM emissions, ultrafine substances emitted during the extrusion of polymer filaments [108], and reduction in $\mathrm{CO}_{2}$ emission through energy efficiency in the manufacturing processes [94,97]. The analysis of the environmental impact of emissions from machine operations as part of AM systems remains an open area of research [109]. Customer involvement in the manufacturing process increases the reduction in transportation and promotes a redistributed model [20]. The manufacturing redistribution, utilization of recycled materials [76,91,93], and reutilization of AM-generated process waste [92] fit well into the CE model. 
For Industry 4.0, cost and sustainable development are key aspects to be considered for AM implementation in a customizable manufacturing environment rather than just a rapid prototyping method [20,101,102]. Therefore, AM's capabilities (computer-aided design, design freedom, and free-from build) and the current environmental requirements make AM highly valuable for Industry 4.0. Cyber-physical systems, cyber-security, blockchain, and AM play an interesting role in a redistributed manufacturing model and promote social sustainability $[5,53]$.

\section{Conclusions}

This systematic literature review analyzed the developments and trends in business innovation and sustainability of AM in the Industry 4.0 context, which includes AM as a technological platform.

First, using a well-structured and replicable literature review, we identified 26 and 52 articles, respectively, on business innovations and sustainability in AM from the existing literature available in online databases. Using the bibliometric data, we established authorship patterns and research clusters. Using descriptive statistics, some plots and tables from $\mathrm{R}$ tool Bibliometrix were presented to analyze the most cited articles, country collaborations, and country-wise literature production on business innovation and sustainability in the context of AM. By classifying the shortlisted articles, we found a relationship between AM and Industry 4.0. This relationship points at AM as an enabler for redistributed manufacturing [20], because it can offer design freedom, on-demand production series [66,68] for tooling [110], and the repair and refurbishment of metal parts [100,111].

Second, based on the data obtained from the literature review, we classified the study areas and found a relationship between them. Different business model proposals consider AM as an enabler for sustainable development and diffusion of CE. AM plays an important role in Industry 4.0, because of its ability to create customizable products, reduce cost for low- and medium-batch sizes, and it material reuse capabilities.

To the best of our knowledge, the existing literature appears to touch upon AM very briefly. Therefore, future research needs to examine and define key aspects of AM for its implementation in Industry 4.0 because of its free-form build capabilities and material potential for CE business proposals. Furthermore, future AM cost models should consider the following variables: the whole production system, tooling for operations, and rapid prototyping, for operational processes, logistics, and the supply chain in general.

Author Contributions: M.P.L. and J.S., gave the conceptual idea and designed the review project. J.R. and J.A.A. verified the analytical methods and supervised the findings of the project with M.P.L. and J.S., L.d.C.N.C. and M.E.H.K. wrote the manuscript and performed the data analysis using the R Bibliometrix software. All authors provided critical inputs and helped shape the research, analysis, and manuscript. All authors have read and agreed to the published version of the manuscript.

Funding: This research received no external funding.

Acknowledgments: The authors gratefully acknowledge the financial support provided by the Santander Foundation for the mobility of Ph.D. students.

Conflicts of Interest: The authors declare no conflict of interest.

\section{References}

1. Attaran, M. The rise of 3-D printing: The advantages of additive manufacturing over traditional manufacturing. Bus. Horiz. 2017, 60, 677-688. [CrossRef]

2. Wohlers, T. Wohlers Report 2015: Additive Manufacturing and 3D printing State of the Industry Annual Worldwide Progress Report. Wohlers Assoc. 2014, 24, 1-34.

3. Bogers, M.; Hadar, R.; Bilberg, A. Additive manufacturing for consumer-centric business models: Implications for supply chains in consumer goods manufacturing. Technol. Forecast. Soc. Chang. 2016, 102, 225-239. [CrossRef]

4. Rayna, T.; Striukova, L. From rapid prototyping to home fabrication: How 3D printing is changing business model innovation. Technol. Forecast. Soc. Chang. 2016, 102, 214-224. [CrossRef] 
5. Thomas, D. Costs, benefits, and adoption of additive manufacturing: A supply chain perspective. Int. J. Adv. Manuf. Technol. 2016, 85, 1857-1876. [CrossRef] [PubMed]

6. Urbanic, R.J.J.; Saqib, S.M.M. A manufacturing cost analysis framework to evaluate machining and fused filament fabrication additive manufacturing approaches. Int. J. Adv. Manuf. Technol. 2019, 102, 3091-3108. [CrossRef]

7. Westerweel, B.; Basten, R.J.I.; van Houtum, G.-J. Traditional or Additive Manufacturing? Assessing Component Design Options through Lifecycle Cost Analysis. Eur. J. Oper. Res. 2018, 270, 570-585. [CrossRef]

8. Thompson, M.K.; Moroni, G.; Vaneker, T.; Fadel, G.; Campbell, R.I.; Gibson, I.; Bernard, A.; Schulz, J.; Graf, P.; Ahuja, B.; et al. Design for Additive Manufacturing: Trends, opportunities, considerations, and constraints. Cirp Ann. Manuf. Technol. 2016, 65, 737-760. [CrossRef]

9. Chen, D.; Heyer, S.; Ibbotson, S.; Salonitis, K.; Steingrímsson, J.G.; Thiede, S.; Steingrimsson, J.G.; Thiede, S.; Steingrímsson, J.G.; Thiede, S.; et al. Direct digital manufacturing: Definition, evolution, and sustainability implications. J. Clean. Prod. 2015, 107, 615-625. [CrossRef]

10. Chitrao, P. 21st C New Technologies a Pathway to Inclusive and Sustainable Growth. Inf. Syst. Des. Intell. Appl. 2016, 434, 395-402.

11. Gwamuri, J.; Franco, D.; Khan, K.Y.; Gauchia, L.; Pearce, J.M. High-Efficiency Solar-Powered 3-D Printers for Sustainable Development. Machines 2016, 4, 3. [CrossRef]

12. Savastano, M.; Bellini, F.; D'Ascenzo, F.; Scornavacca, E. FabLabs as Platforms for Digital Fabrication Services: A Literature Analysis. In Proceedings of the Exploring Services Science, IESS 2017; Za, S., Dragoicea, M., Cavallari, M., Eds.; Gewerbestrasse 11, CH-6330; Springer International Publishing Ag: Cham, Switzerland, 2017; Volume 279, pp. 24-37.

13. Costabile, G.; Fera, M.; Fruggiero, F.; Lambiase, A.; Pham, D. Cost models of additive manufacturing: A literature review. Int. J. Ind. Eng. Comput. 2017, 8, 263-282. [CrossRef]

14. Agrawal, R.; Vinodh, S. State of art review on sustainable additive manufacturing. Rapid Prototyp. J. 2019, 25, 1045-1060. [CrossRef]

15. Godina, R.; Espadinha-Cruz, P.; Ferreira, I.A.; Brás, I.; Matos, F. Knowledge Management and Additive Manufacturing Technology: A Literature Review. In Proceedings of the ECKM 2019 20th European Conference on Knowledge Management 2 VOLS; Academic Conferences and Publishing Limited: Amsterdam, The Nederlands, 2019; p. 398.

16. Savolainen, J.; Collan, M. Additive manufacturing technology and business model change - a review of literature. Addit. Manuf. 2020, 101070. [CrossRef]

17. Lu, Y. Industry 4.0: A Survey on Technologies, Applications and Open Research Issues; Elsevier B.V.: Amsterdam, The Netherlands, 2017; Volume 6, pp. 1-10.

18. Shrouf, F.; Ordieres, J.; Miragliotta, G. Smart factories in Industry 4.0: A review of the concept and of energy management approached in production based on the Internet of Things paradigm. IEEE Int. Conf. Ind. Eng. Eng. Manag. 2014, 2015, 697-701.

19. Qin, J.; Liu, Y.; Grosvenor, R.; Lacan, F.; Jiang, Z. Deep learning-driven particle swarm optimisation for additive manufacturing energy optimisation. J. Clean. Prod. 2020, 245, 118702. [CrossRef]

20. Turner, C.; Moreno, M.; Mondini, L.; Salonitis, K.; Charnley, F.; Tiwari, A.; Hutabarat, W. Sustainable Production in a Circular Economy: A Business Model for Re-Distributed Manufacturing. Sustainability 2019, 11, 4291. [CrossRef]

21. Asociación Española de Normalización y Certificación. Norma Española Fabricación aditiva Principios generales ISO/ASTM 52900:2015; Asociación Española de Normalización y Certificación: Madrid, Spain, 2017.

22. Blaya, F.; San Pedro, P.; Lopez Silva, J.; D'Amato, R.; Soriano Heras, E.; Antonio Juanes, J.; Pedro, P.S.; Silva, J.L.; D'Amato, R.; Heras, E.S.; et al. Design of an Orthopedic Product by Using Additive Manufacturing Technology: The Arm Splint. J. Med. Syst. 2018, 42, 54. [CrossRef]

23. Dias, M.R.; Guedes, J.M.; Flanagan, C.L.; Hollister, S.J.; Fernandes, P.R. Optimization of scaffold design for bone tissue engineering: A computational and experimental study. Med. Eng. Phys. 2014, 36, 448-457. [CrossRef]

24. Santolaria, J.; Monge, R.; Tobajas, Á.; Jimenez, R.; Cabrera, M.A.; Fernandez, L.J. Design, manufacture and geometric verification of rapid prototyped microfluidic encapsulations by computed tomography. Comput. Ind. 2013. [CrossRef] 
25. Sutradhar, A.; Park, J.; Carrau, D.; Nguyen, T.H.; Miller, M.J.; Paulino, G.H.; Nguyen, T.H.; Miller, M.J.; Paulino, G.H. Designing patient-specific 3D printed craniofacial implants using a novel topology optimization method. Med. Biol. Eng. Comput. 2016, 54, 1123-1135. [CrossRef] [PubMed]

26. Zadpoor, A.A. Design for Additive Bio-Manufacturing: From Patient-Specific Medical Devices to Rationally Designed Meta-Biomaterials. Int. J. Mol. Sci. 2017, 18, 1607. [CrossRef] [PubMed]

27. Holzmann, P.; Breitenecker, R.J.R.J.R.J.; Soomro, A.A.A.A.; Schwarz, E.J.E.J. User entrepreneur business models in 3D printing. J. Manuf. Technol. Manag. 2017, 28, 75-94. [CrossRef]

28. Laplume, A.; Anzalone, G.C.G.C.; Pearce, J.M.J.M. Open-source, self-replicating 3-D printer factory for small-business manufacturing. Int. J. Adv. Manuf. Technol. 2016, 85, 633-642. [CrossRef]

29. Rong, K.; Patton, D.; Chen, W. Business models dynamics and business ecosystems in the emerging 3D printing industry. Technol. Forecast. Soc. Chang. 2018, 134, 234-245. [CrossRef]

30. Chen, C.; Shen, Y.; Tsai, H.-L. A Foil-Based Additive Manufacturing Technology for Metal Parts. J. Manuf. Sci. Eng. 2016, 139, 024501. [CrossRef]

31. Murmura, F.; Bravi, L. Additive manufacturing in the wood-furniture sector: Sustainability of the technology, benefits and limitations of adoption. J. Manuf. Technol. Manag. 2018, 29, 350-371. [CrossRef]

32. Zhong, S.; Pearce, J.M. Tightening the loop on the circular economy: Coupled distributed recycling and manufacturing with recyclebot and RepRap 3-D printing. Resour. Conserv. Recycl. 2018, 128, 48-58. [CrossRef]

33. Miao, X.; Zhang, Q.; Atkin, C.; Sun, Z.; Li, Y. Improving Purge Air Cooling Effectiveness by Engineered End-Wall SurfaceStructures-Part I: Duct Flow. J. Turbomach. Trans. Asme 2018, 140.

34. Pelanconi, M.; Barbato, M.; Zavattoni, S.; Vignoles, G.L.; Ortona, A. Thermal design, optimization and additive manufacturing of ceramic regular structures to maximize the radiative heat transfer. Mater. Des. 2019, 163. [CrossRef]

35. Wu, J.; Clausen, A.; Sigmund, O. Minimum compliance topology optimization of shell-infill composites foradditive manufacturing. Comput. Methods Appl. Mech. Eng. 2017, 326, 358-375. [CrossRef]

36. Mattos Nascimento, D.L.; Alencastro, V.; Goncalves Quelhas, O.L.; Gusmao Caiado, R.G.; Garza-Reyes, J.A.J.A.J.A.; Lona, L.R.L.R.L.R.; Tortorella, G.; Nascimento, D.L.M.D.L.M.; Alencastro, V.; Quelhas, O.L.G.O.L.G.; et al. Exploring Industry 4.0 technologies to enable circular economy practices in a manufacturing context A business model proposal. J. Manuf. Technol. Manag. 2019, 30, 607-627. [CrossRef]

37. Ghobakhloo, M. The future of manufacturing industry: A strategic roadmap toward Industry 4.0. J. Manuf. Technol. Manag. 2018, 29, 910-936. [CrossRef]

38. Atzeni, E.; Iuliano, L.; Minetola, P.; Salmi, A. Redesign and cost estimation of rapid manufactured plastic parts. Rapid Prototyp. J. 2010, 16, 308-317. [CrossRef]

39. Telenko, C.; Seepersad, C.C. A comparison of the energy efficiency of selective laser sintering and injection molding of nylon parts. Rapid Prototyp. J. 2012, 18, 472-481. [CrossRef]

40. Hopkinson, N.; Dickens, P. Analysis of rapid manufacturing-using layer manufacturing processes for production. Mech. Eng. Sci. 2003, 217, 31-39. [CrossRef]

41. Amir Sasson, J.C.J. The 3D printing order: Variability, supercenters and supply chain reconfigurations. Int. J. Phys. Distrib. Logist. Manag. 2016, 46, 88-94.

42. Santander, P.; Cruz, F.; Boudaoud, H.; Camargo, M. 3D-Printing based distributed plastic recycling: A conceptual model for closed-loop supply chain design. In Proceedings of the 2018 IEEE International Conference on Engineering, Technology and Innovation (ICE/ITMC), Stuttgart, Germany, 17-20 June 2018.

43. Santos, G.; Murmura, F.; Bravi, L. Fabrication laboratories: The development of new business models with new digital technologies. J. Manuf. Technol. Manag. 2018, 29, 1332-1357. [CrossRef]

44. Mosconi, F. The New European Industrial Policy: Global Competitiveness and the Manufacturing Renaissance; Routledge-Taylor and Francis Group: Oxfordshire, UK, 2015; ISBN 9781317646129.

45. Roblek, V.; Meško, M.; Krapež, A. A Complex View of Industry 4.0. Sage Open 2016, 6, 215824401665398. [CrossRef]

46. Egger, J.; Masood, T. Augmented reality in support of intelligent manufacturing-A systematic literature review. Comput. Ind. Eng. 2020, 140. [CrossRef]

47. Xu, L.D.; Xu, E.L.; Li, L. Industry 4.0: State of the art and future trends. Int. J. Prod. Res. 2018, 56, $2941-2962$. [CrossRef]

48. Baheti, R.; Gill, H. Cyber-physical Systems. Impact Control Technol. 2011, 12, 161-166. 
49. Manyika, J.; Chui, M.; Bughin, J.; Dobbs, R.; Bisson, P.; Marrs, A. Disruptive Technologies: Advances that Will Transform Life, Business, and the Global Economy; McKinsey Global Institute: New York, NY, USA, 2013.

50. Lasi, H.; Fettke, P.; Kemper, H.G.; Feld, T.; Hoffmann, M. Industry 4.0. Bus. Inf. Syst. Eng. 2014, 6, $239-242$. [CrossRef]

51. Kamble, S.S.; Gunasekaran, A.; Gawankar, S.A. Sustainable Industry 4.0 framework: A systematic literature review identifying the current trends and future perspectives. Process Saf. Environ. Prot. 2018, 117, 408-425. [CrossRef]

52. Beatriz, A.; De Sousa, L.; Charbel, J.; Chiappetta, J.; Godinho, M.; David, F. Industry 4.0 and the circular economy: A proposed research agenda and original roadmap for sustainable operations. Ann. Oper. Res. 2018, 270, 273-286.

53. Dev, N.K.; Shankar, R.; Hasan, F. Resources, Conservation \& Recycling Industry 4.0 and circular economy: Operational excellence for sustainable reverse supply chain performance. Resour. Conserv. Recycl. 2020, 153, 104583.

54. Bienhaus, F.; Haddud, A. Procurement 4.0: Factors influencing the digitisation of procurement and supply chains. Bus. Process Manag. J. 2018, 24, 965-984. [CrossRef]

55. Ibarra, D.; Ganzarain, J.; Igartua, J.I. Business model innovation through Industry 4.0: A review. In Proceedings of the Procedia Manufacturing; Elsevier B.V.: Amsterdam, The Netherlands, 2018; Volume 22, pp. 4-10.

56. Ren, L.; Wang, S.; Shen, Y.; Hong, S.; Chen, Y.; Zhang, L. 3D Printing in Cloud Manufacturing: Model and Platform Design. In Proceedings of the Proceedings of the ASME 11th International Manufacturing Science and Engineering Conference, Blacksburg, VA, USA, 27 June-1 July 2016.

57. Ivanov, D.; Dolgui, A.; Sokolov, B. The impact of digital technology and Industry 4.0 on the ripple effect and supply chain risk analytics. Int. J. Prod. Res. 2019, 57, 829-846. [CrossRef]

58. Heck, S.; Rogers, M.; Carroll, P. Resource revolution: How to Capture the Biggest Business Opportunity in a Century; Houghton Mifflin Harcourt: Boston, MA, USA, 2014.

59. Moher, D.; Liberati, A.; Tetzlaff, J.; Altman, D.G.; Altman, D.; Antes, G.; Atkins, D.; Barbour, V.; Barrowman, N.; Berlin, J.A.; et al. Preferred reporting items for systematic reviews and meta-analyses: The PRISMA statement. PLoS Med. 2009, 6, e1000097. [CrossRef]

60. Aghaei Chadegani, A.; Salehi, H.; Md Yunus, M.M.; Farhadi, H.; Fooladi, M.; Farhadi, M.; Ale Ebrahim, N. A comparison between two main academic literature collections: Web of science and scopus databases. Asian Soc. Sci. 2013, 9, 18-26. [CrossRef]

61. Persson, O.; Danell, R.; Schneider, J.W. How to use Bibexcel for various types of bibliometric analysis. In Celebrating Scholarly Communication Studies: A Festschrift for Olle Persson at His 60th Birthday; Åström, F., Danell, R., Larsen, B., Schneider, J., Eds.; International Society for Scientometrics and Informetrics: Leuven, Belgium, 2009; pp. 9-24.

62. Aria, M.; Cuccurullo, C. Bibliometrix: An R-tool for comprehensive science mapping analysis. J. Informetr. 2017, 11, 959-975. [CrossRef]

63. Wittbrodt, B.T.T.; Glover, A.G.G.; Laureto, J.; Anzalone, G.C.C.; Oppliger, D.; Irwin, J.L.L.; Pearce, J.M.M. Life-cycle economic analysis of distributed manufacturing with open-source 3-D printers. Mechatronics 2013, 23, 713-726. [CrossRef]

64. ASTM International. ASTM F2792-09 Standard Terminology for Additive Manufacturing Technologies; ASTM International: West Conshohocken, PA, USA, 2012.

65. Atzeni, E.; Salmi, A. Economics of additive manufacturing for end-usable metal parts. Int. J. Adv. Manuf. Technol. 2012, 62, 1147-1155. [CrossRef]

66. Ruffo, M.; Tuck, C.; Hague, R. Cost estimation for rapid manufacturing - laser sintering production for low to medium volumes. Proc. Inst. Mech. Eng. Part B-J. Eng. Manuf. 2006, 220, 1417-1427. [CrossRef]

67. Rickenbacher, L.; Spierings, A.; Wegener, K. An integrated cost-model for selective laser melting (SLM). Rapid Prototyp. J. 2013, 19, 208-214. [CrossRef]

68. Ruffo, M.; Hague, R. Cost estimation for rapid manufacturing - Simultaneous production of mixed components using laser sintering. Proc. Inst. Mech. Eng. Part B J. Eng. Manuf. 2007, 221, 1585-1591. [CrossRef]

69. Subburaj, K.; Ravi, B. Computer aided rapid tooling process selection and manufacturability evaluation for injection mold development. Comput. Ind. 2008, 59, 262-276. [CrossRef]

70. Jia, F.; Wang, X.; Mustafee, N.; Hao, L. Investigating the feasibility of supply chain-centric business models in 3D chocolate printing: A simulation study. Technol. Forecast. Soc. Chang. 2016, 102, 202-213. [CrossRef] 
71. Folgado, R.; Peças, P.; Henriques, E. Life cycle cost for technology selection: A Case study in the manufacturing of injection moulds. Int. J. Prod. Econ. 2010, 128, 368-378. [CrossRef]

72. Gebler, M.; Uiterkamp, A.J.M.S.; Visser, C. A global sustainability perspective on 3D printing technologies. Energy Policy 2014, 74, 158-167. [CrossRef]

73. Despeisse, M.; Baumers, M.; Brown, P.; Charnley, F.; Ford, S.J.; Garmulewicz, A.; Knowles, S.; Minshall, T.H.W.; Mortara, L.; Reed-Tsochas, F.P.; et al. Unlocking value for a circular economy through 3D printing: A research agenda. Technol. Forecast. Soc. Chang. 2017, 115, 75-84. [CrossRef]

74. Bordin, A.; Sartori, S.; Bruschi, S.; Ghiotti, A. Experimental investigation on the feasibility of dry and cryogenic machining as sustainable strategies when turning Ti6Al4V produced by Additive Manufacturing. J. Clean. Prod. 2017, 142, 4142-4151. [CrossRef]

75. Tang, Y.; Mak, K.; Zhao, Y.F. A framework to reduce product environmental impact through design optimization for additive manufacturing. J. Clean. Prod. 2016, 137, 1560-1572. [CrossRef]

76. Kucherov, F.A.; Gordeev, E.G.; Kashin, A.S.; Ananikov, V.P. Three-Dimensional Printing with Biomass-Derived PEF for Carbon-Neutral Manufacturing. Angew. Chem. Int. Ed. 2017, 56, 15931-15935. [CrossRef] [PubMed]

77. Priarone, P.C.; Ingarao, G. Towards criteria for sustainable process selection: On the modelling of pure subtractive versus additive/subtractive integrated manufacturing approaches. J. Clean. Prod. 2017, 144, 57-68. [CrossRef]

78. Voet, V.S.D.; Strating, T.; Schnelting, G.H.M.; Dijkstra, P.; Tietema, M.; Xu, J.; Woortman, A.J.J.; Loos, K.; Jager, J.; Folkersma, R. Biobased Acrylate Photocurable Resin Formulation for Stereolithography 3D Printing. Acs Omega 2018, 3, 1403-1408. [CrossRef]

79. Ruffo, M.; Tuck, C.; Hague, R. Empirical laser sintering time estimator for Duraform PA. Int. J. Prod. Res. 2006, 44, 5131-5146. [CrossRef]

80. Baumers, M.; Dickens, P.; Tuck, C.; Hague, R. The cost of additive manufacturing: Machine productivity, economies of scale and technology-push. Technol. Forecast. Soc. Chang. 2016, 102, 193-201. [CrossRef]

81. Fera, M.; Fruggiero, F.; Costabile, G.; Lambiase, A.; Pham, D.T.T. A new mixed production cost allocation model for additive manufacturing (MiProCAMAM). Int. J. Adv. Manuf. Technol. 2017, 92, 4275-4291. [CrossRef]

82. Yang, Y.; Li, L. Cost modeling and analysis for Mask Image Projection Stereolithography additive manufacturing: Simultaneous production with mixed geometries. Int. J. Prod. Econ. 2018, 206, 146-158. [CrossRef]

83. Campbell, I. Stereolithography build time estimation based on volumetric calculations. Rapid Prototyp. J. 2008, 14, 271-279. [CrossRef]

84. Ingole, D.S.; Deshmukh, T.R.; Kuthe, A.M.; Ashtankar, K.M. Build orientation analysis for minimum cost determination in FDM. Proc. Inst. Mech. Eng. Part B-J. Eng. Manuf. 2011, 225, 1925-1938. [CrossRef]

85. Alexander, P.; Allen, S.; Dutta, D. Part orientation and build cost determination in layered manufacturing. Comput. Des. 1998, 30, 343-356. [CrossRef]

86. Flammini, S.; Arcese, G.; Lucchetti, M.C.M.C.; Mortara, L. Business model configuration and dynamics for technology commercialization in mature markets. Br. Food J. 2017, 119, 2340-2358. [CrossRef]

87. The Ellen MacArthur Foundation What is a Circular Economy? Ellen MacArthur Foundation. Available online: https://www.ellenmacarthurfoundation.org/circular-economy/concept (accessed on 5 October 2019).

88. Sauerwein, M.; Doubrovski, E.; Balkenende, R.; Bakker, C. Exploring the potential of additive manufacturing for product design in a circular economy. J. Clean. Prod. 2019, 226, 1138-1149. [CrossRef]

89. Byard, D.J.; Woern, A.L.; Oakley, R.B.; Fiedler, M.J.; Snabes, S.L.; Pearce, J.M. Green fab lab applications of large-area waste polymer-based additive manufacturing. Addit. Manuf. 2019, 27, 515-525. [CrossRef]

90. Leino, M.; Pekkarinen, J.; Soukka, R. The role of laser additive manufacturing methods of metals in repair, refurbishment and remanufacturing-Enabling circular economy. Phys. Procedia 2016, 83, 752-760. [CrossRef]

91. Woern, A.L.; Byard, D.J.; Oakley, R.B.; Fiedler, M.J.; Snabes, S.L.; Pearce, J.M. Fused Particle Fabrication 3-D Printing: Recycled Materials' Optimization and Mechanical Properties. Materials 2018, 11, 1413. [CrossRef]

92. Paciorek-Sadowska, J.; Borowicz, M.; Isbrandt, M. New Poly(lactide-urethane-isocyanurate) Foams Based on Bio-Polylactide Waste. Polymers 2019, 11, 481. [CrossRef]

93. Reich, M.J.; Woern, A.L.; Tanikella, N.G.; Pearce, J.M. Mechanical Properties and Applications of Recycled Polycarbonate Particle Material Extrusion-Based Additive Manufacturing. Materials 2019, 12, 1642. [CrossRef] [PubMed] 
94. Yang, Y.; Li, L.; Pan, Y.; Sun, Z. Energy Consumption Modeling of Stereolithography-Based Additive Manufacturing Toward Environmental Sustainability. J. Ind. Ecol. 2017, 21, S168-S178. [CrossRef]

95. Kamps, T.; Lutter-Guenther, M.; Seidel, C.; Gutowski, T.; Reinhart, G. Cost- and energy-efficient manufacture of gears by laser beam melting. Cirp J. Manuf. Sci. Technol. 2018, 21, 47-60. [CrossRef]

96. Yang, S.; Min, W.; Ghibaudo, J.; Zhao, Y.F. Understanding the sustainability potential of part consolidation design supported by additive manufacturing. J. Clean. Prod. 2019, 232, 722-738. [CrossRef]

97. Xu, J.; Wang, K.; Sheng, H.; Gao, M.; Zhang, S.; Tan, J. Energy efficiency optimization for ecological 3D printing based on adaptive multi-layer customization. J. Clean. Prod. 2020, 245. [CrossRef]

98. Bours, J.; Adzima, B.; Gladwin, S.; Cabral, J.; Mau, S. Addressing Hazardous Implications of Additive Manufacturing: Complementing Life Cycle Assessment with a Framework for Evaluating Direct Human Health and Environmental Impacts. J. Ind. Ecol. 2017, 21, S25-S36. [CrossRef]

99. Priarone, P.C.; Campatelli, G.; Montevecchi, F.; Venturini, G.; Settineri, L. A modelling framework for comparing the environmental and economic performance of WAAM-based integrated manufacturing and machining. Cirp Ann. Technol. 2019, 68, 37-40. [CrossRef]

100. Wahab, D.A.; Azman, A.H. Additive Manufacturing for Repair and Restoration in Remanufacturing: An Overview from Object Design and Systems Perspectives. Processes 2019, 7, 802.

101. Saboori, A.; Aversa, A.; Marchese, G.; Biamino, S.; Lombardi, M.; Fino, P. Application of Directed Energy Deposition-Based Additive Manufacturing in Repair. Appl. Sci. 2019, 9, 3316. [CrossRef]

102. Yang, S.; Zhao, Y.F. Additive Manufacturing-Enabled Part Count Reduction: A Lifecycle Perspective. J. Mech. Des. 2018, 140. [CrossRef]

103. Verma, A.; Rai, R. Sustainability-induced dual-level optimization of additive manufacturing process. Int. J. Adv. Manuf. Technol. 2017, 88, 1945-1959. [CrossRef]

104. Canciglieri, O.J.; Sant'Anna, Â.M.O.; Machado, L.C. Multi-attribute method for prioritization of sustainable prototyping technologies. Clean Technol. Environ. Policy 2015, 17, 1355-1363. [CrossRef]

105. Lazarov, B.S.; Sigmund, O.; Meyer, K.E.; Alexandersen, J. Experimental validation of additively manufactured optimized shapes for passive cooling. Appl. Energy 2018, 226, 330-339. [CrossRef]

106. Al-Ghamdi, K.A. Sustainable FDM additive manufacturing of ABS components with emphasis on energy minimized and time efficient lightweight construction. Int. J. Light. Mater. Manuf. 2019, 2, 338-345. [CrossRef]

107. Bonnín Roca, J.; Vaishnav, P.; Laureijs, R.E.E.; Mendonça, J.; Fuchs, E.R.H.R.H. Technology cost drivers for a potential transition to decentralized manufacturing. Addit. Manuf. 2019, 28, 136-151. [CrossRef]

108. Faludi, J.; Van Sice, C.M.; Shi, Y.; Bower, J.; Brooks, O.M.K. Novel materials can radically improve whole-system environmental impacts of additive manufacturing. J. Clean. Prod. 2019, 212, 1580-1590. [CrossRef]

109. Stephens, B.; Azimi, P.; El Orch, Z.; Ramos, T. Ultrafine particle emissions from desktop 3D printers. Atmos. Environ. 2013, 79, 334-339. [CrossRef]

110. Yi, L.; Glaessner, C.; Aurich, J.C.J.C.; Gläßner, C.; Aurich, J.C.J.C.; Glaessner, C.; Aurich, J.C.J.C. How to integrate additive manufacturing technologies into manufacturing systems successfully: A perspective from the commercial vehicle industry. J. Manuf. Syst. 2019, 53, 195-211. [CrossRef]

111. Knofius, N.; van der Heijden, M.C.; Zijm, W.H.M. Consolidating spare parts for asset maintenance with additive manufacturing. Int. J. Prod. Econ. 2019, 208, 269-280. [CrossRef]

(C) 2020 by the authors. Licensee MDPI, Basel, Switzerland. This article is an open access article distributed under the terms and conditions of the Creative Commons Attribution (CC BY) license (http://creativecommons.org/licenses/by/4.0/). 